\title{
HCV IRES domain IIb affects the configuration of coding RNA in the 40S subunit's decoding groove
}

\author{
MEGAN E. FILBIN ${ }^{1}$ and JEFFREY S. KIEFT ${ }^{1,2,3}$ \\ ${ }^{1}$ Department of Biochemistry and Molecular Genetics, University of Colorado Denver, School of Medicine, Aurora, Colorado 80045, USA \\ ${ }^{2}$ Howard Hughes Medical Institute, University of Colorado Denver, School of Medicine, Aurora, Colorado 80045, USA
}

\begin{abstract}
Hepatitis C virus (HCV) uses a structured internal ribosome entry site (IRES) RNA to recruit the translation machinery to the viral RNA and begin protein synthesis without the ribosomal scanning process required for canonical translation initiation. Different IRES structural domains are used in this process, which begins with direct binding of the $40 \mathrm{~S}$ ribosomal subunit to the IRES RNA and involves specific manipulation of the translational machinery. We have found that upon initial 40S subunit binding, the stem-loop domain of the IRES that contains the start codon unwinds and adopts a stable configuration within the subunit's decoding groove. This configuration depends on the sequence and structure of a different stem-loop domain (domain IIb) located far from the start codon in sequence, but spatially proximal in the IRES $40 \mathrm{~S}$ complex. Mutation of domain IIb results in misconfiguration of the HCV RNA in the decoding groove that includes changes in the placement of the AUG start codon, and a substantial decrease in the ability of the IRES to initiate translation. Our results show that two distal regions of the IRES are structurally communicating at the initial step of $40 \mathrm{~S}$ subunit binding and suggest that this is an important step in driving protein synthesis.
\end{abstract}

Keywords: HCV IRES; translation initiation; mRNA structure; RNA structure; RNA probing

\section{INTRODUCTION}

Hepatitis $\mathrm{C}$ virus (HCV) is a human pathogen responsible for millions of chronic infections that can progress to severe cirrhosis and hepatocellular carcinoma. The virus consists of a single-stranded RNA molecule that is both the viral genome and the template for translation of the viral proteins. However, unlike cellular messenger RNA (mRNA), the HCV RNA is not capped or polyadenylated and, thus, to recruit the translation machinery it uses an internal ribosome entry site (IRES)-driven mechanism (Tsukiyama-Kohara et al. 1992; Wang et al. 1993), which differs dramatically from the canonical cap-dependent initiation pathway (for review, see Fraser and Doudna 2007). Specifically, in canonical eukaryotic translation initiation, the $7 \mathrm{mG}$ cap and over a dozen eukaryotic initiation factor (eIF) proteins are needed to recruit the small ribosomal subunit, help it scan the message to find the correct start codon (usually AUG), assemble the $80 \mathrm{~S}$ ribosome, and proceed to protein synthesis (for review, see Pestova et al. 2007). In contrast, the HCV RNA recruits

\footnotetext{
${ }^{3}$ Corresponding author.

E-mail Jeffrey.Kieft@ucdenver.edu.

Article published online ahead of print. Article and publication date are at http://www.rnajournal.org/cgi/doi/10.1261/rna.2594011.
}

the small ribosomal subunit using a direct interaction between the RNA and the subunit; there is no need for a cap, there is no scanning, and only a subset of initiation factors are necessary to form an $80 \mathrm{~S}$ ribosome on the IRES RNA (Pestova et al. 1998). This cap- and scanning-independent mechanism is driven by specific sequences and structures within the HCV IRES RNA (for review, see Fraser and Doudna 2007; Lukavsky 2009), which is similar to other IRESs found in pestiviruses (Brown et al. 1992; Sizova et al. 1998; Pestova and Hellen 1999; Kolupaeva et al. 2000b), as well as some picornaviruses (Pisarev et al. 2004; Hellen and de Breyne 2007; de Breyne et al. 2008; Easton et al. 2009).

The HCV IRES possesses a structured but extended conformation containing three major structural domains (II-IV) spanning 330 nt (Brown et al. 1992; Wang et al. 1995; Kieft et al. 1999), with different structural elements acting at specific steps to assemble the translation machinery and drive translation initiation (Fig. 1A). First, several elements of domain III bind the $40 \mathrm{~S}$ subunit directly to the IRES (Kolupaeva et al. 2000a; Kieft et al. 2001; Lytle et al. 2001, 2002). In this HCV IRES•40S subunit binary complex, domain II (dII) contacts the 40S subunit over the decoding groove (Spahn et al. 2001). The interaction of domain II with the $40 \mathrm{~S}$ subunit is not necessary for binding (Kieft 
A

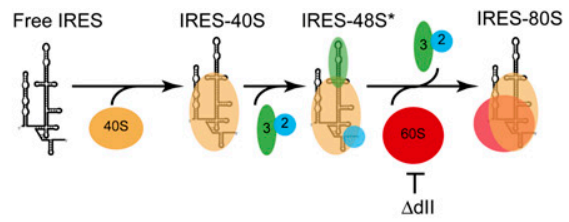

B

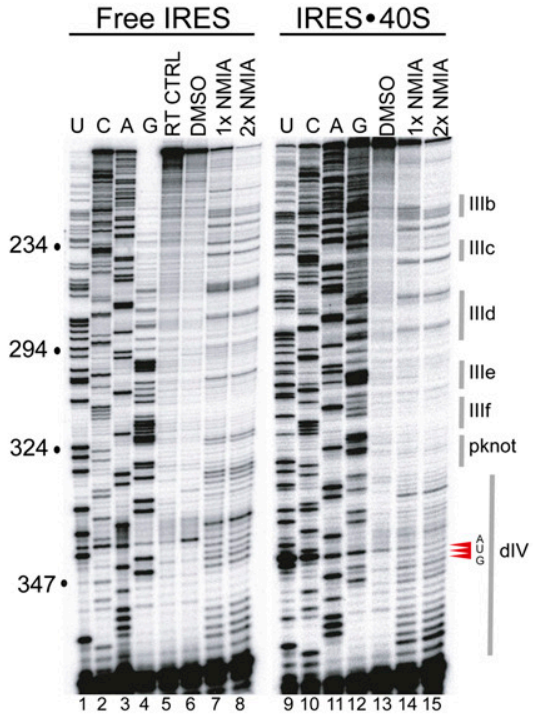

C

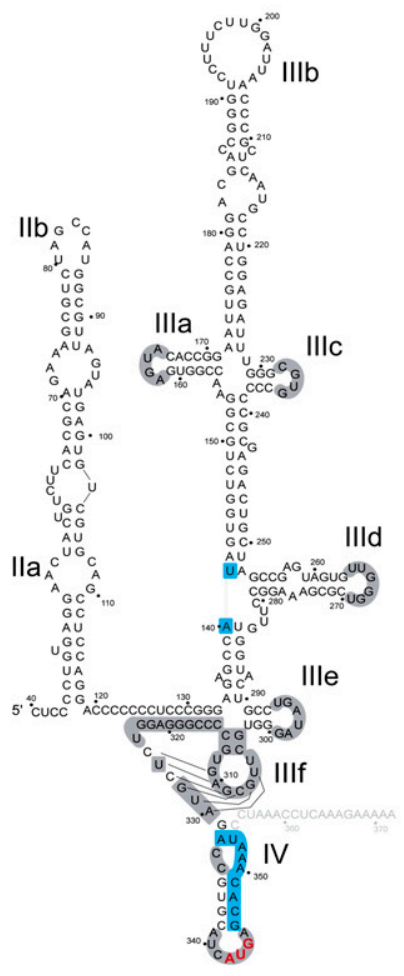

D

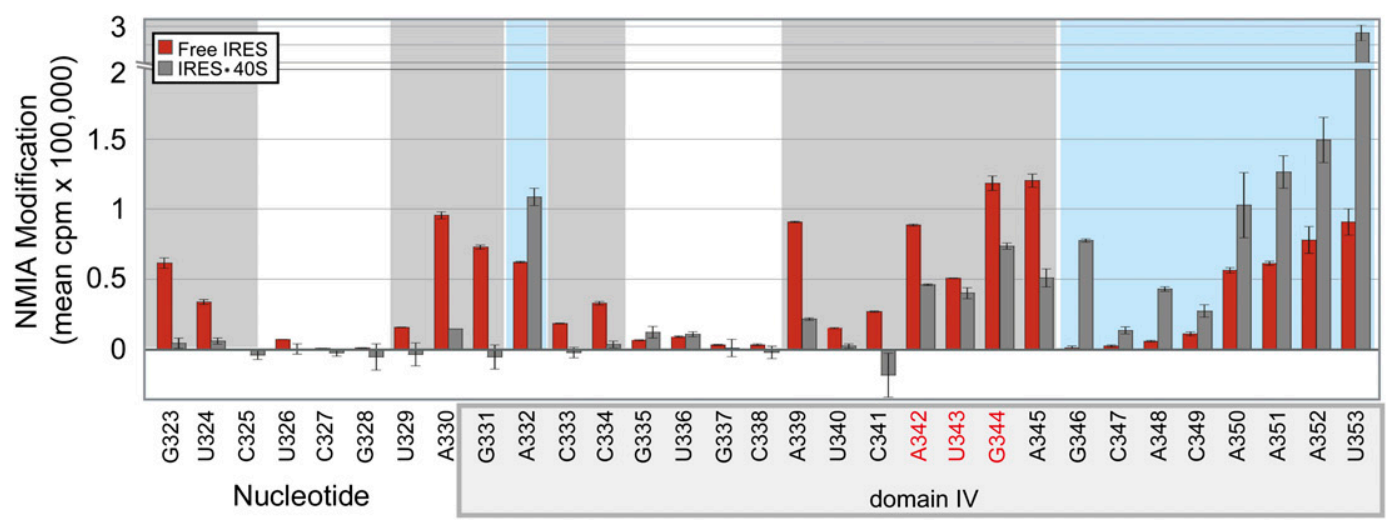

FIGURE 1. SHAPE analysis of wild-type HCV IRES RNA in the unbound and 40S-bound forms. (A) Schematic of HCV IRES translation initiation where the IRES first binds the 40 S subunit (orange), then eukaryotic initiation factor (eIF) 3 (green), and the ternary complex (eIF2GTP-Met-tRNA $A_{i}$ Met , blue), followed by GTP hydrolysis and eIF release. The $60 \mathrm{~S}$ subunit (red) then joins to form an $80 \mathrm{~S}$ ribosome. Removal of domain II $(\Delta \mathrm{dII})$ blocks the formation of 80 S ribosomes. (B) Representative SHAPE analysis gel of full-length HCV IRES RNA in the free form (left) and $40 \mathrm{~S}$ subunit-bound form (right). Lanes containing free RNA or bound to the 40S subunit are labeled, reactions lanes are marked as NMIA (two concentrations of NMIA are shown), control lanes are marked as DMSO (DMSO added, no NMIA) and RT (no DMSO or NMIA added). Lanes 1-4,9-12 are the sequencing reactions. Reference nucleotide numbers are bulleted on the left and the parts of the gel that correspond to different IRES secondary structural elements are indicated by gray bars to the right. The location of the start codon AUG is indicated with red arrowheads. $(C)$ Secondary structure of the full-length HCV IRES RNA, where decreases in NMIA modification upon 40S subunit binding are designated with gray, and regions with increases in modification are in blue. Structural elements are labeled. The nucleotides $3^{\prime}$ of domain IV (faded gray) are not visible in this analysis, as this is where the primer anneals for reverse-transcription. $(D)$ Quantitated, normalized, and background-corrected modification data from two independent SHAPE probing experiments, with error bars representing one standard deviation from the mean of both experiments. The experiment was repeated three additional times (data not shown), and the replicates validate the quantitated data shown here. The degree of modification is on the $y$-axis; each nucleotide is on the $x$-axis with the start codon AUG colored red and the location of domain IV indicated. Red bars indicate free IRES; gray bars are 40S bound IRES. Gray regions indicate a decrease in modification upon 40S subunit binding and cyan regions indicate an increase in SHAPE modification upon the addition of the 40S subunit. 
et al. 2001), but it does alter the subunit's conformation (Spahn et al. 2001) in a manner reminiscent of the change induced by eIF1 and eIF1A binding to the ribosomal subunit (Passmore et al. 2007). Initial binding of the $40 \mathrm{~S}$ subunit is followed by recruitment of eIF3 and the eIF2•Met$\mathrm{tRNA}_{\mathrm{i}}{ }^{\mathrm{Met}} \cdot \mathrm{GTP}$ ternary complex to form the $48 \mathrm{~S}^{*}$ complex (asterisk denotes a $48 \mathrm{~S}$ that differs from one produced by canonical initiation), which relies on the four-way junction of domain III (dIIIabc), domain IIIb (dIIIb), and the AUG codon, respectively (Sizova et al. 1998; Kolupaeva et al. 2000a; Kieft et al. 2001; Collier et al. 2002; Ji et al. 2004; Otto and Puglisi 2004). DII then acts to promote the removal of eIF3j (Fraser et al. 2009) and hydrolysis of GTP by eIF2 (Locker et al. 2007), triggering the release of protein factors and recruitment of the 60S subunit to form an $80 \mathrm{~S}$ ribosome. Remarkably, under some conditions, the IRES can operate without eIF2 (Pestova et al. 2008; Terenin et al. 2008). Thus, is it clear that the HCV IRES (and likely related IRESs) operate by not only binding to, but manipulating the ribosome and a subset of eIFs. However, many details of the HCV IRES RNA's structure-based mechanism remain undiscovered.

Although the structures of several individual structural elements of the HCV and Classical Swine Fever Virus IRES RNAs have been solved by X-ray crystallography and NMR (Klinck et al. 2000; Lukavsky et al. 2000, 2003; Collier et al. 2002; Kieft et al. 2002; Dibrov et al. 2007; Locker et al. 2007), one aspect of HCV IRES function that is unexplored is the degree to which conformational changes in the IRES RNA are coupled to, or important for, specific steps in translation initiation. It has been shown that the intergenic region IRESs from the Dicistroviridae undergo local conformational changes during preinitiation complex formation in functionally important regions (Costantino et al. 2008; Pfingsten et al. 2010). This, along with the fact that the ribosome undergoes conformational changes during initiation (Hellen 2009) suggests the HCV IRES RNA might also change structure during preinitiation complex formation. Thus, while the involvement of different IRES structural domains in different steps of translation initiation has been mapped, the way in which these domains change structure during the progression: free IRES $\rightarrow$ IRES•40S subunit $\rightarrow$ IRES•48S* complex $\rightarrow$ IRES•80S ribosome $\rightarrow$ elongation has not been directly investigated. Regions in the HCV IRES that undergo functionally important changes in structure or whose structure can be altered may be good inhibitor targets (Paulsen et al. 2010).

To explore the presence and role of functionally important structural changes in the HCV IRES, we have used a combination of mutagenesis, chemical probing, footprinting, toeprinting, and translation assays to query the IRES RNA structure in the free (unbound) form as well as the $40 \mathrm{~S}$ subunit-bound form, and to relate these changes to function. We have discovered that interaction of the IRES with the translation machinery induces structural changes in the conformation of the IRES near the AUG start codon, which appear to be important for function. We have also found that these conformational changes depend on the sequence at the apical loop of domain II (subdomain IIb; dIIb). Mutating dIIb affects not only the structure of the AUG-harboring domain IV (dIV) when bound to the $40 \mathrm{~S}$ decoding groove and its placement in the $40 \mathrm{~S}$ subunit's P-site, but also reduces the IRES' ability to initiate translation. These findings indicate the existence of a functionally important long-range interaction between two IRES domains, distal in sequence but proximal in space, which occurs immediately after $40 \mathrm{~S}$ subunit binding.

\section{RESULTS}

\section{The HCV IRES RNA changes structure upon 40S subunit binding}

To query the structure of the HCV RNA backbone in the free and 40S subunit-bound states, we used selective 2' hydroxyl acylation analyzed by primer extension (SHAPE), a chemical probing method that modifies the 2 ' hydroxyl of conformationally dynamic nucleotides (such as in singlestranded regions) or those constrained in a reactive conformation (e.g. C2'-endo) (Merino et al. 2005). Under conditions optimal for single hit kinetics (Fig. 1B, cf. lanes 8 and 7), we observe that the unbound wild-type (WT) IRES is modified in regions of the RNA that are predicted to be single-stranded, including stem-loops IIIc, IIIa, IIId, and IIIe (Fig. 1B, cf. lanes 6 and 7; Fig. 1C). Hence, our probing is consistent with the secondary structure model shown in Figure 1C. Notably, many of these modified regions are known to interact directly with the translation machinery (Kolupaeva et al. 2000a; Kieft et al. 2001; Lytle et al. 2001, 2002). As expected, probing of the WT IRES•40S subunit binary complex showed that many areas known to interact with the $40 \mathrm{~S}$ subunit are modified less compared with the unbound state (Fig. 1B, cf. lanes 14 and 7; Fig. 1C). This is consistent with these regions becoming protected from modification upon interacting with the $40 \mathrm{~S}$ subunit. Thus, the SHAPE experiment faithfully reports previously identified sites of $40 \mathrm{~S}$ subunit interaction with the IRES and also indicates that the subunit is bound in our experiments. In contrast to the regions that become protected, parts of dIV, which contains the AUG start codon (Fig. 1C, red), and must therefore interact with the decoding groove, are modified more when bound to the $40 \mathrm{~S}$ subunit than when not bound. To clearly define this effect, multiple independent experimental replicates were quantitated and normalized, and the background-corrected data were graphed (Fig. 1D). These data show that nucleotides 332 and 346-353 show a reproducible increase in modification upon $40 \mathrm{~S}$ subunit binding, suggesting that these nucleotides are becoming more flexible or single stranded (Fig. 1B, cf. lanes 14-7; Fig.1D, blue-shaded region). This is 
significant because the dIV stem-loop must unfold in order for the AUG start codon to be placed in the P-site of the $40 \mathrm{~S}$ subunit, and is consistent with a report indicating that stabilizing dIV's structure inhibits initiation (Honda et al. 1996). Our SHAPE results show that initial 40S subunit binding to the IRES destabilizes dIV's stem-loop, likely making the AUG codon and adjacent RNA available for interactions with the translation machinery. Interestingly, the increased modification is primarily in RNA that is downstream ( $\left.3^{\prime}\right)$ from the start codon, while nucleotides upstream $\left(5^{\prime}\right)$ of the start codon are modified less than those downstream (Fig. 1C,D). This is notable, because one would expect that disruption of the dIV helix would lead to single-stranded RNA (and greater modification) both upstream of and downstream from the AUG start codon. The observed modification pattern is therefore consistent with the dIV stem-loop unwinding upon $40 \mathrm{~S}$ binding, with regions upstream of the AUG adopting a stable configuration within the decoding groove, and the regions downstream from the AUG remaining conformationally dynamic.

\section{Domain II affects the configuration of the RNA in the decoding groove}

DII of the HCV IRES is known to alter the conformation of the $40 \mathrm{~S}$ subunit, and this domain docks on the $40 \mathrm{~S}$ subunit over the E-site for tRNA binding (Spahn et al. 2001); thus, we hypothesized that dII might be involved in the conformational changes of dIV upon $40 \mathrm{~S}$ binding. To test this, and to look for structural changes that occur in a functionally deficient mutant IRES as compared with WT IRES, we conducted SHAPE using an HCV IRES RNA missing dII ( $\Delta \mathrm{dII})$. This mutant has been shown to bind to the $40 \mathrm{~S}$ subunit with wild-type affinity, but to be inhibited in its ability to progress to $80 \mathrm{~S}$ ribosomes (Kieft et al. 2001; Ji et al. 2004; Otto and Puglisi 2004). We conducted SHAPE on unbound $\Delta \mathrm{dII}$ and found little difference compared with the modifications apparent in the unbound WT IRES RNA (Fig. 2A, cf. lanes 7 and 11; Fig. 2C). This is consistent with the fact that the rest of the IRES folds independently of domain II (Kieft et al. 1999). We also conducted SHAPE on the $\Delta$ dII॰40S subunit complex and found decreases in modification in areas known to contact the 40S subunit, similar to WT (Fig. 2A, cf. lanes 9,7 with 13,11; Fig. 2B,C), again indicating correct subunit binding in our experiment, as expected, because dII is not necessary for initial IRES•40S subunit complex formation (Kieft et al. 2001; OdremanMacchioli et al. 2001; Otto and Puglisi 2004). However, unlike bound WT RNA, the 40S subunit-bound $\Delta$ dII had increased modification of nucleotides not only $3^{\prime}$ of the start codon, but also $5^{\prime}$ of the AUG start codon, specifically at the $5^{\prime}$ end of dIV (Fig. 2A, cf. lanes 9 and 13; Fig. 2C, bottom). Nucleotides 329-331 and 333-339 were modified more in $\Delta \mathrm{dII} \bullet 40 \mathrm{~S}$ than in bound WT॰40S (Fig. 2B,C). Thus, while in WT IRES•40S, the $5^{\prime}$ half of dIV appears to adopt a specific structured configuration in the decoding groove, removal of dII disfavors this structure.

\section{Domain IV structure is affected by subdomain IIb in the IRES•40S subunit complex}

Our observation that removal of dII alters the configuration of the RNA in the decoding groove led us to investigate what part of dII is responsible for this effect. We noted that the sequence of the apical loop of dIIb is conserved among some IRES RNAs with structures similar to HCV's, including a lesser-related picornavirus (Brown et al. 1992; Honda et al. 1999; Rijnbrand et al. 2000; Hellen and de Breyne 2007). This suggests that this sequence might be important for IRES activity. Likewise, in the 40S subunitbound IRES, dIIb is placed within the decoding groove, where the AUG start codon and adjacent RNA must dock. To illustrate this spatial proximity, we constructed a model of the placement of dII and the start codon in the P site from the cryo-EM reconstructions of the HCV IRES RNA bound to the 40S subunit (Spahn et al. 2001), the crystal structure of the 40S subunit from Tetrahymena thermophila (Rabl et al. 2011), the NMR structure of domain II of the HCV IRES RNA (Lukavsky et al. 2003), and the crystal structure of the Thermus thermophilus 70S ribosome with tRNAs and mRNA bound (Fig. 3A; Selmer et al. 2006). This model has little or no steric clash and motivated us to explore the role of the apical loop of dII (dIIb) in greater detail.

To determine whether the change in the configuration of the RNA in the decoding groove is due specifically to dIIb, we designed a set of full-length IRESs with mutations in the conserved region of dIIb (Fig. 3B) and analyzed these by SHAPE. In all of these mutants, $40 \mathrm{~S}$ subunit binding causes increased RNA modification to nucleotides in dIV in a manner that is similar to $\Delta$ dII. In particular, like $\Delta$ dII, all of the dIIb mutants show an increase in modification upstream of the AUG codon compared with WT (Fig. 3C, cf. lanes 9,13,17 with lane 21; Fig. 3D, lower graph). Thus, the configuration of the RNA in the decoding groove relies not only on the presence of dII, but on the specific sequence of dIIb. Whether or not the differences in SHAPE modification between the dIIb mutants and WT is due to the conformation of the $40 \mathrm{~S}$ subunit when these mutant IRES RNAs are bound remains to be determined. However, considering that the dIIb mutants retain the ability to make extensive contacts to the $40 \mathrm{~S}$ subunit, similarly to WT, it is likely that the dIIb mutants induce the same or a similar $40 \mathrm{~S}$ subunit conformational change as does the WT IRES.

\section{HCV IRES RNA dIIb is important for translation initiation}

The fact that dIIb mutations affect the local structure of the RNA in the vicinity of the start codon led us to ask whether this effect is correlated with the ability of the IRES to 
A

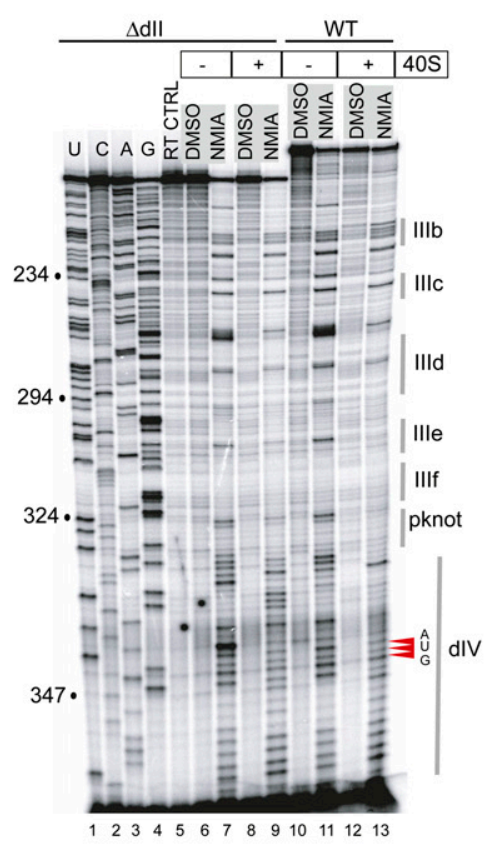

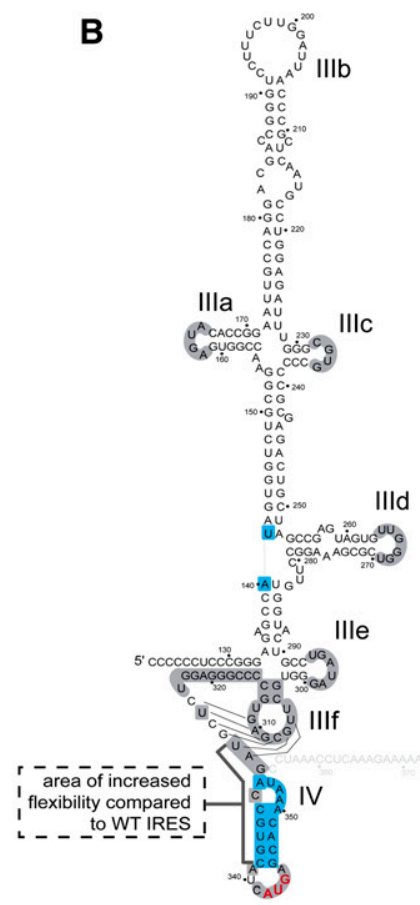

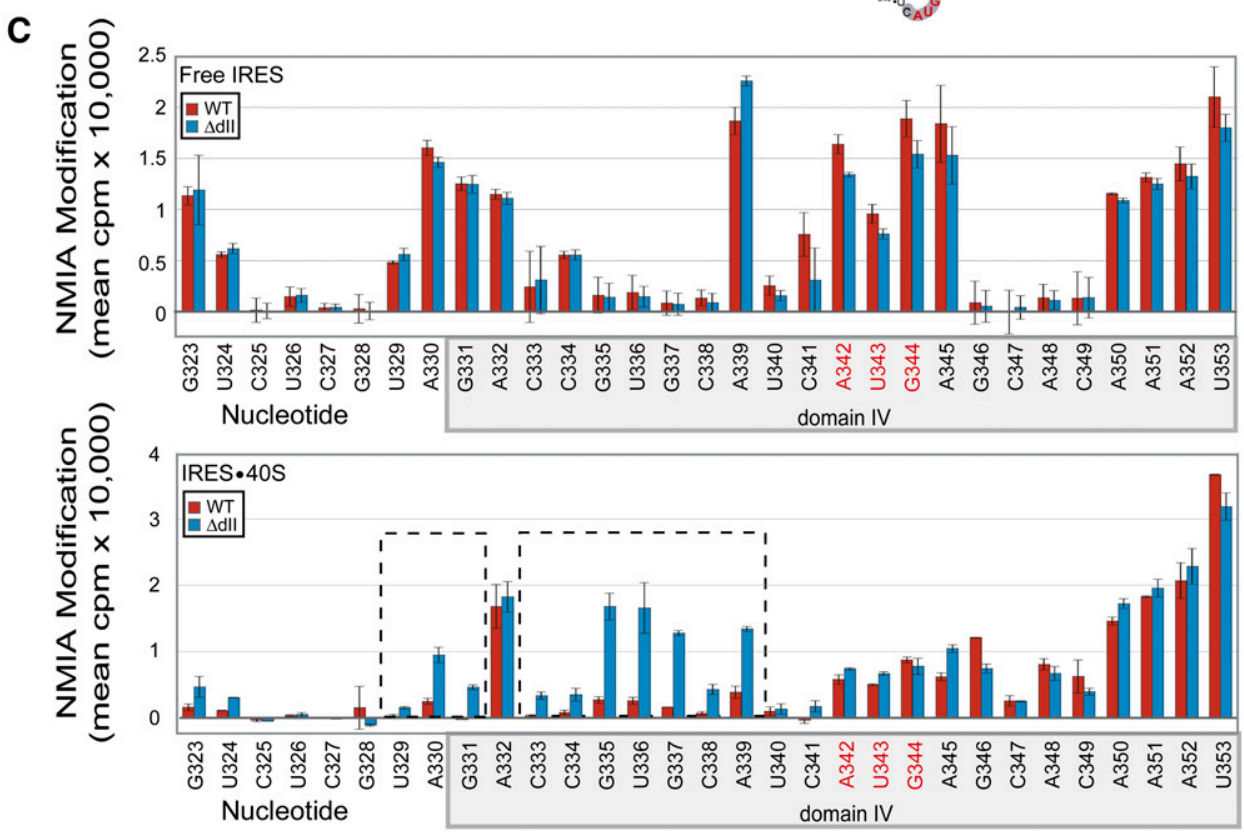

FIGURE 2. SHAPE analysis of $\triangle$ dII HCV IRES RNA in the unbound and 40S-bound forms. (A) Representative SHAPE analysis gel of WT fulllength and $\triangle$ dII HCV IRES RNAs in the free (unbound) form and $40 S$ subunit-bound form. Lanes containing free RNA or bound to the 40S subunit are labeled, reaction lanes are marked as NMIA, control lanes are marked as DMSO (DMSO added, no NMIA) and RT (no DMSO or NMIA added). Lanes 1-4 contain the sequencing reactions. Reference nucleotide numbers are bulleted on the left and the parts of the gel that correspond to different IRES secondary structural elements are indicated by gray bars to the right. The location of the start codon AUG is indicated with red arrowheads. (B) Secondary structure of the $\Delta$ dII HCV IRES RNA where decreases in NMIA modification due to 40 S subunit binding are designated with gray and regions with increases in modification upon 40 S subunit binding are in blue. Structural elements are labeled. The nucleotides $3^{\prime}$ of domain IV (faded gray) are not visible in this analysis, as this is where the primer anneals for reverse-transcription. The part of the $\Delta$ dII IRES RNA that shows a different modification than WT full-length IRES, when bound to the 40S subunit, is indicated. (C) Quantitated, normalized, and background-corrected modification data from two independent SHAPE probing experiments, with error bars representing one standard deviation from the mean of both. The experiment was repeated three additional times (data not shown), and the replicates validate the quantitated data shown here. The degree of modification is on the $y$-axis, each nucleotide is on the $x$-axis, with the start codon AUG colored red and the location of domain IV indicated. Red bars indicate full-length IRES, blue bars are $\Delta$ dII IRES. The top graph contains the modifications for each RNA in the free form; the bottom graph contains a comparison of modifications on each RNA in the 40S subunit-bound form. The dashed box indicates regions that change in their modification pattern when domain II is removed. 
initiate translation. To answer this, we tested the ability of the aforementioned dIIb mutants to translate a downstream luciferase (LUC) reporter sequence in rabbit reticulocyte lysate (RRL). To present the IRES in a more physiologically authentic context, we used an uncapped monocistronic RNA template as opposed to a bicistronic system (Fig. 4A).
The quality of the template RNA was assayed by gel electrophoresis, and identical amounts were used in all reactions (Fig. 4B). Measuring LUC activity after 90 min showed that all three dIIb mutants produce roughly half as much protein as does WT, but are not as defective as $\Delta$ dII (Fig. $4 \mathrm{C})$. Decreased translation is not due to a difference in
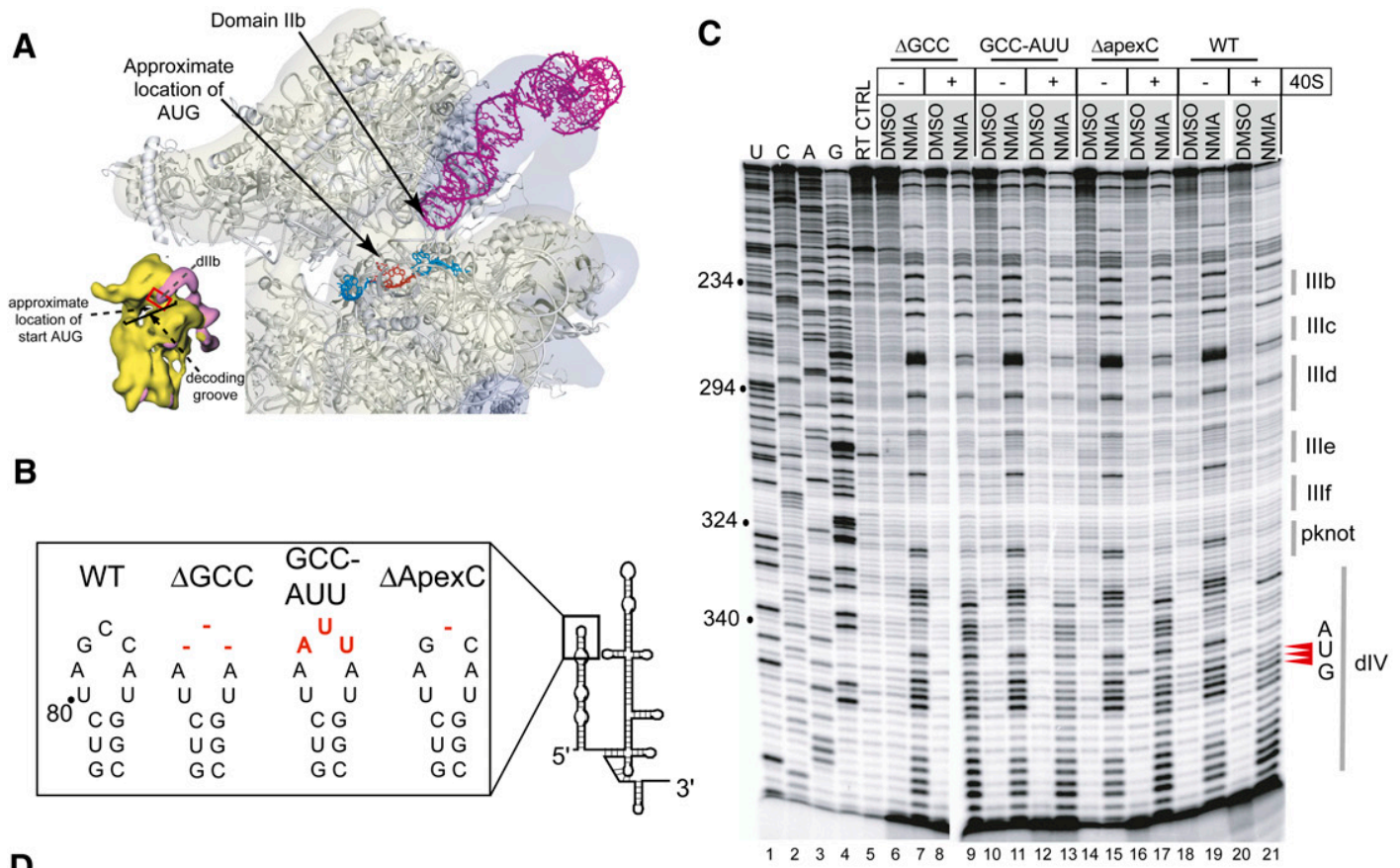

D
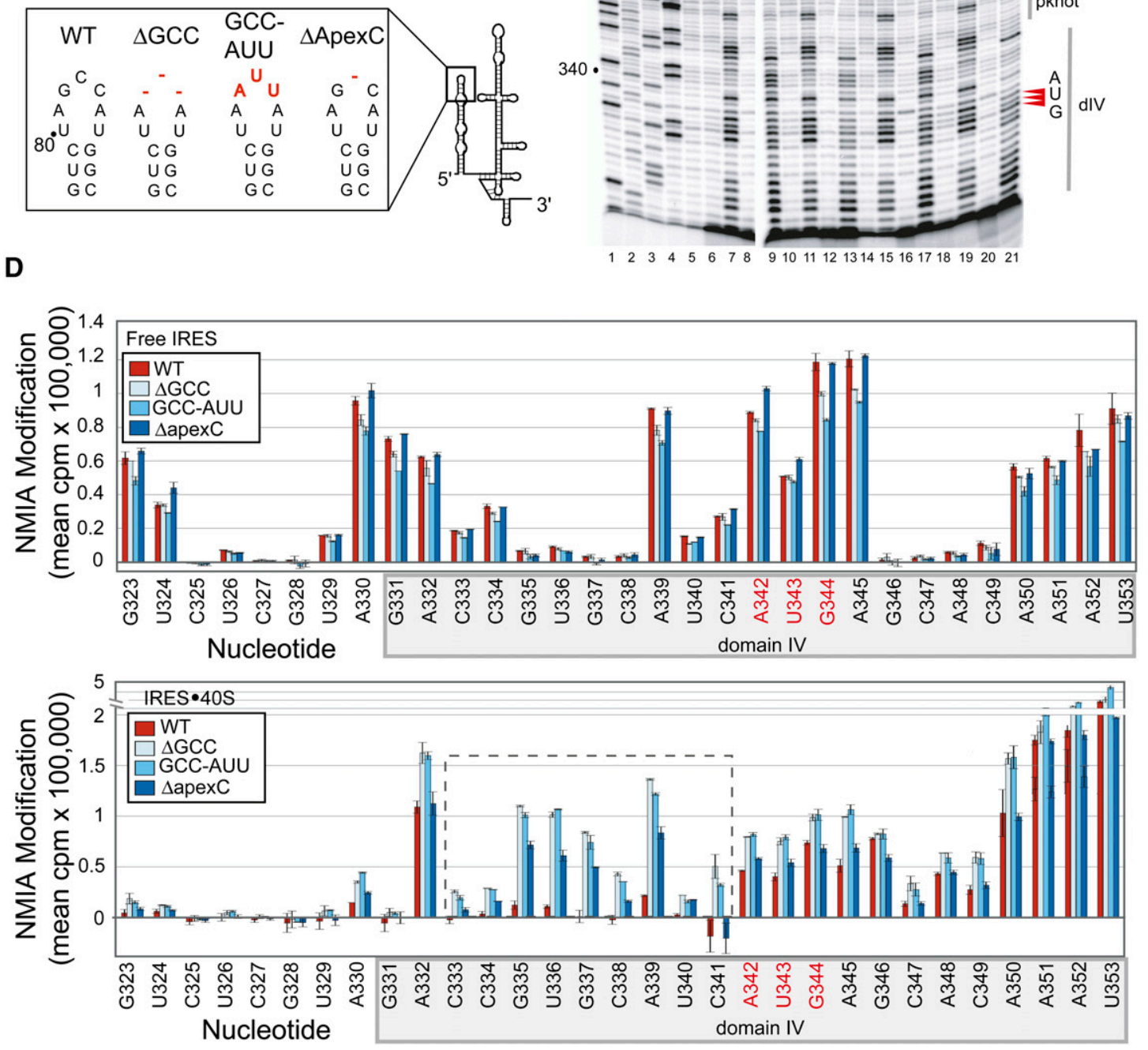

FIGURE 3. (Legend on next page) 
degradation rates of the dIIb mutant IRES-containing RNAs as compared with WT IRES during the course of the in vitro translation (Fig. 4D, cf. lanes 6-25 and lanes 1-5; Fig.4E). These results show that dIIb is important for HCV IRESmediated translation initiation. In fact, deleting only a single base (C83) at the apex of the stem-loop ( $\Delta$ apexC) is sufficient to substantially decrease IRES function. The fact that these mutants decrease IRES-driven initiation by $\sim 50 \%$ are consistent with the interpretation that while removal of all of dII blocks important steps, mutation of just dIIb likely slows or inhibits a different step. Likewise, this effect coincides with previous work showing decreases in translation due to various mutations made to dIIb (Odreman-Macchioli et al. 2001; Kalliampakou et al. 2002; Otto and Puglisi 2004). The different SHAPE modification patterns observed with these mutants further supports this interpretation (Fig. 3). Taken together, our data show that the previously described translational defects due to mutations in dIIb, as well as our specific dIIb mutations, correlate with a misconfiguration of the dIIb mutant IRES RNA in the decoding groove of the $40 \mathrm{~S}$ subunit.

\section{Domain II is still positioned correctly in dIIb mutants}

What is the mechanism by which mutating dIIb affects the configuration of the RNA in the decoding groove and the function of the IRES? One possibility is that mutations in dIIb could cause dII to move from its normal position over the E-site of the $40 \mathrm{~S}$ subunit and thus not be docked in position (Fig. 3A). This could then cause a change in the conformation of the $40 \mathrm{~S}$ subunit similar to that observed when dII is removed completely (Spahn et al. 2001). This seems unlikely, as the dIIb mutants retain $\sim 50 \%$ initiation activity, while $\Delta$ dII's activity is almost abolished (Fig. 4). Nonetheless, to directly assay for domain II docking on the $40 \mathrm{~S}$ subunit, we used the fact that within the HCV IRES.40S subunit binary complex, nucleotide G82 is protected from RNase $\mathrm{T} 1$ cleavage by the interaction of
dII with the 40S subunit (Kieft et al. 2001). RNase T1 footprinting of IIb mutant $\Delta$ apexC (chosen because it is the only dIIb mutant that has G82) reveals that G82 in $\Delta$ apexC is protected by $40 \mathrm{~S}$ subunit binding to the same degree as in WT RNA (Fig. 5A, cf. lanes 5 and 8; Fig. 5B). This is consistent with the tip of the dIIb mutants being docked into a position on the $40 \mathrm{~S}$ subunit similar to WT. In addition, SHAPE analysis of the local structure of dIIb in the unbound (data not shown) and IRES•40S binary complex, shows that every dIIb mutant has increased flexibility of the RNA (as compared with WT), exclusively in the tip of dIIb, but not elsewhere in dII, when the IRES is bound to the 40S subunit (Fig. 5C). The low reactivity of the WT (in both unbound and IRES 40 S complex states) is consistent with the presence of a stable structure formed by dIIb, as observed by NMR (Lukavsky et al. 2003), which is locally disrupted by mutation. Hence, we find no evidence that our dIIb mutations disrupt the overall placement of dII on the $40 \mathrm{~S}$ subunit. Rather, the mutations likely disrupt a very specific structure within dIIb, and a local interaction within the decoding groove, near the start AUG.

\section{Communication between dIIb and dIV is likely not through base-pairing}

The observed dIIb mutation-induced changes in dIV structure in the IRES•40S subunit complex raises the question of how these two domains communicate structurally. The presence of a direct IRES RNA-IRES RNA interaction between these domains is suggested by the potential for basepairing between nucleotides 84 and 87 (in dIIb) and 341 and 344 (in dIV) in the HCV IRES (Fig. 6A,B; Lafuente et al. 2002). The presence of this possible base-pairing led us to compare the sequences of other HCV-like IRESs for which secondary structures have been proposed (Pestova and Hellen 1999; Hellen and de Breyne 2007). This comparison shows that the sequence of dIIb is not well conserved among HCV-like IRES sequences. In particular, the

FIGURE 3. SHAPE analysis of dIIb mutants. (A) Model of the placement of domain II and the start codon in the P-site built from the cryo-EM reconstruction of the HCV IRES RNA bound to the 40S subunit (Spahn et al. 2001) (pale transparent yellow and magenta surface), the crystal structure of the 40S subunit from Tetrahymena thermophila (white ribbons) (Rabl et al. 2011), the NMR structure of domain II of the HCV IRES RNA (magenta) (Lukavsky et al. 2003), and the crystal structure of the Thermus thermophilus 70S ribosome with tRNAs and mRNA bound (Selmer et al. 2006) (the mRNA from this structure is shown in blue with the AUG in the P-site in red). This model has little or no steric clash and matches all structural information very well. The model shows the proximity of the tip of domain II (dIIb) to the decoding groove and to the RNA surrounding the AUG. The cryo-EM reconstruction (Spahn et al. 2001) of the full-length IRES (magenta) bound to the 40S subunit (yellow) is inset for reference. DIIb is indicated, and the region where nucleotide G82 is located is indicated by the red box, and the decoding groove and approximate location of the AUG are labeled. (B) Secondary structure cartoon of the HCV IRES with dIIb indicated. Mutants used in this analysis are shown. $(C)$ Representative SHAPE analysis gel of the WT full-length IRES and each of the dIIb mutants. Reactions with or without bound 40S subunit $(+/-40 \mathrm{~S})$ are in lanes $6-21$, the sequencing ladder is in lanes $1-4$, and the reverse transcription (RT) control is in lane 5. Reference nucleotide numbers are bulleted on the left and secondary structural domains indicated by gray bars on the right of the gel. The location of the start codon AUG is indicated with red arrowheads. $(D)$ Quantitated, normalized, and background-corrected modification data from two independent SHAPE probing experiments, with the error bars representing one standard deviation from the mean of both. The experiment was repeated two additional times (data not shown), and the replicates validate the quantitated data shown here. The degree of modification is on the $y$-axis, each nucleotide is on the $x$-axis with the start codon AUG colored red and the location of domain IV indicated. Red bars indicate WT IRES, bars in different shades of blue indicate the dIIb mutant IRESs. The top graph contains the modifications for each RNA in the free form; the bottom graph contains a comparison of modifications on each RNA in the 40S subunit-bound form. The dashed box indicates regions that change in their modification pattern (relative to WT) when dIIb is mutated. 
A

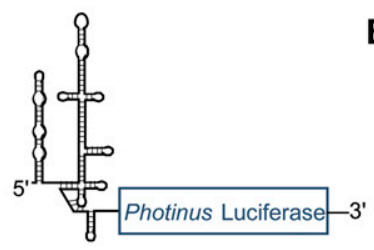

D
B

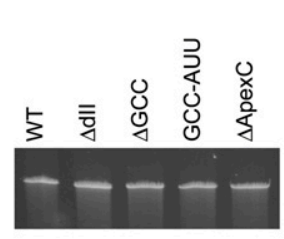

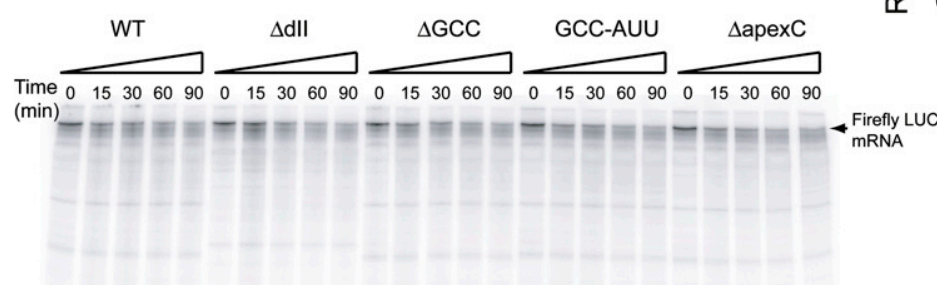

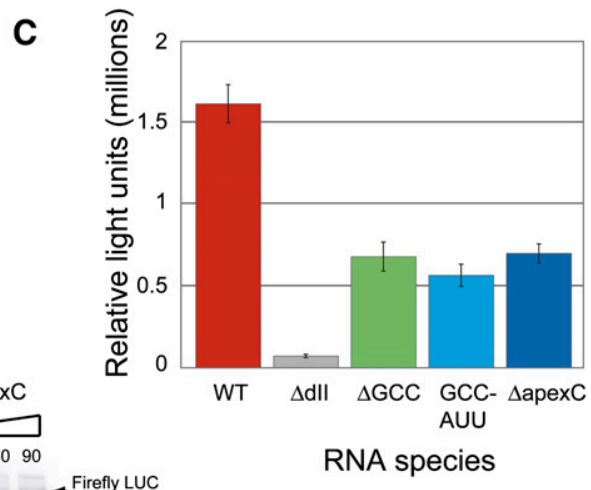

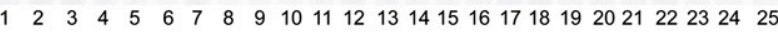

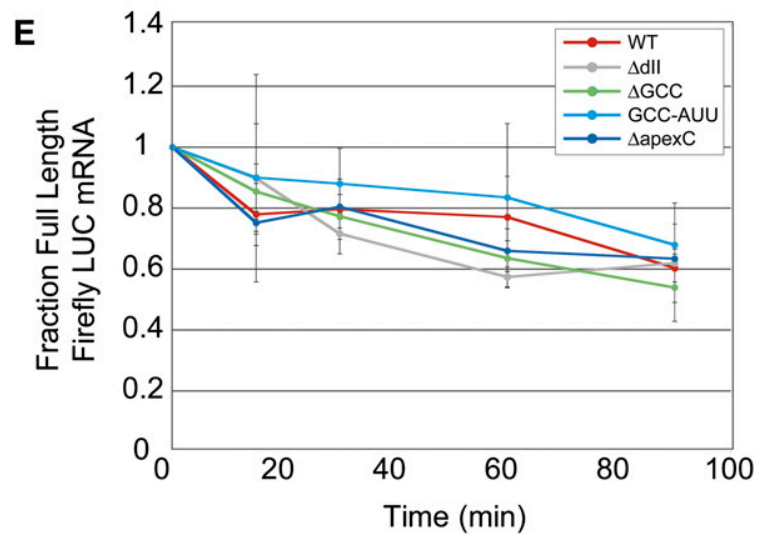

FIGURE 4. In vitro translation initiation assays of WT and mutant IRES RNAs. (A) Diagram of the uncapped monocistronic reporter construct used in these assays. $(B)$ Denaturing gel of each IRES containing reporter construct showing that all RNAs are homogenous in species and concentration. (C) Level of Photinus luciferase after $90 \mathrm{~min}$ for WT, $\Delta \mathrm{dII}$, and each dIIb mutant. Error bars represent one standard error from the mean of three independent, triplicate experiments. $(D)$ Comparison of the degradation rates of internally radiolabeled WT and dIIb mutant reporter mRNAs in RRL over the course of the experiment. $(E)$ Graph of the degradation rates of WT and dIIb mutant reporter RNAs in RRL over a 90-min time course. Error bars represent one standard deviation from the mean of three experiments.

$5^{\prime}$-CAU-3' sequence at the $3^{\prime}$ end of dIIb that would pair with the AUG (the start codon necessary for function) is only found in four of the 11 sequences compared (Fig. 6A). If $\mathrm{G} \bullet \mathrm{U}$ base-pairs are considered in addition to $\mathrm{A}-\mathrm{U}$ and $\mathrm{G}-\mathrm{C}$ pairs, then some sort of pairing can be proposed for each sequence, but there is ambiguity in exactly where the pairing could occur. In addition, the nature, precise position, and predicted thermodynamic stability strength of the putative interaction is variable in different IRESs. These facts argue against simple base-pairing as the source of the dII-dIV communication within 40S-bound HCV-like IRES. In addition, examination of our model of the IRES $\mathrm{dII}$ and start codon position on the $40 \mathrm{~S}$ subunit indicates that the relevant bases in $\mathrm{dIIb}$ are $29 \AA-30 \AA$ from their potential pairing partners (Fig. 6B). Movement of dIIb to pair with the AUG would place dII in a position to clash with tRNA in the $\mathrm{P}$ site (in the $48 \mathrm{~S}^{\star}$ complex) and would also not match the cryo-EM density (Spahn et al. 2001). Likewise, movement of the AUG to pair with the docked position of dIIb would move the AUG far from the P site and make it unavailable for interaction with the initiator tRNA.

Despite these arguments, to directly test the possibility of base-pairing between dIIb and dIV within the IRES 40 S subunit complex, we repeated SHAPE analysis using mutants that either disrupt or restore this putative basepairing interaction (Fig. 6C). Mutant dIV_AGUAC is designed to disrupt putative base paring between dIV and dIIb on the dIV half of the interaction. This mutation does not cause changes in the SHAPE modification pattern in domain IIb (Fig. 6D, top graph), nor in dIV when compared with WT (Fig. 6D, bottom graph), suggesting that no base-pairing interactions were disrupted by this mutation. Mutant dII_GUACC, designed to disrupt the putative 


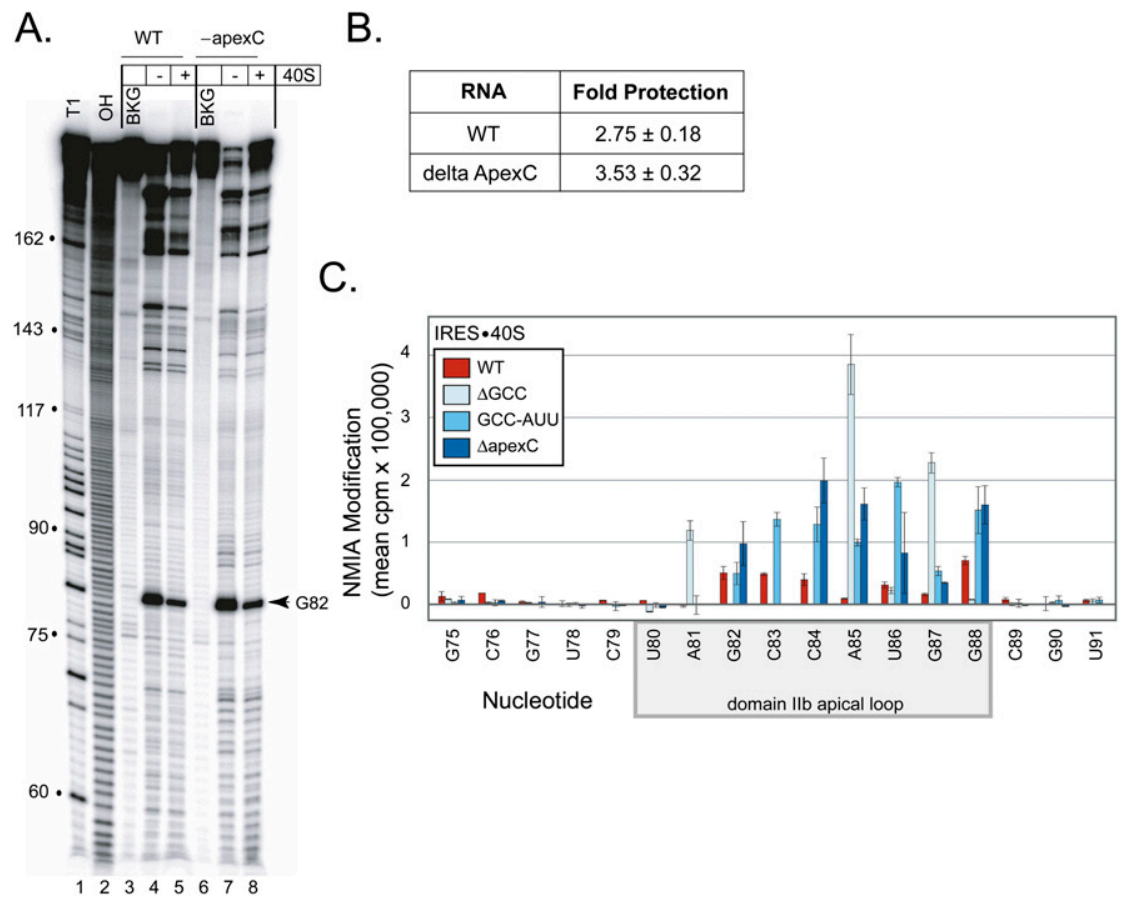

FIGURE 5. Domain IIb mutants interact with the $40 \mathrm{~S}$ subunit properly. (A) RNase T1 footprinting gel with G82 cleavage indicated by the arrowhead. Lanes with and without bound $40 \mathrm{~S}$ subunit are shown. A RNase T1 ladder made under denaturing conditions and a hydrolysis ladder are marked as $\mathrm{T} 1$ and $\mathrm{OH}$, respectively. BKG lane is a no-RNase T1 control. (B) Quantified and normalized G82 bands from the gel in $A$ show that the G82 of the $\triangle$ apexC mutant RNA is protected to the same degree as is WT. (C) Quantitated, normalized, and background-corrected modification data from two independent SHAPE probing experiments of the WT and dIIb mutant IRESs in the 40S subunit-bound form with an additional repeat (data not shown), validating the quantitated data shown here. Error bars represent one standard deviation from the mean of both independent experiments. The degree of modification is on the $y$-axis; each nucleotide is on the $x$-axis. Red bars indicate WT IRES; bars in different shades of blue indicate the dIIb mutant IRESs. The part of the gel corresponding to the tip of domain IIb (dIIb) is indicated.

interaction on the dIIb half, causes an increase in modification within dIIb (Fig. 6D, top graph) and has a modification pattern (and decreased translation initiation; data not shown) similar to the other dIIb mutants (Fig. 6D, bottom graph). SHAPE probing in the double mutant (dII/ IV_restore), which would restore the putative base-pairing interaction, results in a modification pattern more similar to dII_GUACC than WT, suggesting that no base-pairs have been restored (Fig. 6D). Together, these data are not consistent with base-pairing between dII and dIV in the fully formed HCV IRES•40S subunit complex. This agrees with published results in which no cross-linking was observed between these distal elements (Laletina et al. 2006; Locker et al. 2007; Babaylova et al. 2009). Furthermore, considering that our $\Delta$ apexC dIIb mutant, which does not alter the putative base-pairing interaction, produces the same SHAPE modifications as the $\triangle$ GCC and GCC-AUU dIIb mutants, it seems unlikely that a base-pairing interaction between dIIb and dIV accounts for our results. Hence, while we cannot completely rule out the possibility that pairing occurs at some other point during IRES-driven translation, our results suggest it does not occur in the HCV IRES•40S subunit complex.

\section{Subdomain IIb is important for placement of the RNA in the decoding groove}

The fact that mutating dIIb affects the configuration of mRNA in the decoding groove upstream of the start codon leads to the hypothesis that the mutations affect the proper placement of the coding RNA, overall, to include the AUG in the P-site. To explore this, we used toeprinting analysis, which interrogates positioning of the AUG start codon in the P-site and has been applied to HCV IRES-ribosome complexes. We performed toeprinting on WT, $\Delta$ dII, and the dIIb mutants in the unbound form and bound to purified $40 \mathrm{~S}$ subunits. As expected, we observe no substantial toeprint on free RNAs (Fig. 7A, lanes $5,7,9,11,13$ ), but upon $40 \mathrm{~S}$ binding, both WT and $\Delta$ dII RNAs produced a strong toeprint at nucleotides $+15 / 16$ (where A in AUG is +1 ), although the $\Delta$ dII toeprint is weaker (Fig. 7A, cf. lanes 6 and 8; Fig. 7B). This result is consistent with AUG placement in the P-site as shown in previous studies (Locker et al. 2007). We also observed a second stop a few nucleotides $5^{\prime}$ of this position (+9-11), perhaps indicating the previously reported ability of the reverse transcriptase to penetrate a few nucleotides into the decoding groove of an HCV IRES•40S subunit binary complex (Pestova et al. 1998). In contrast, the dIIb mutants bound to $40 \mathrm{~S}$ subunit exhibit a much weaker toeprint at the $+15 / 16$ position and the second, $+9-11$ stop is stronger compared with both WT and $\Delta$ dII (Fig. 7A, cf. lanes 6,8 and 10,12,14; Fig. 7B). Considering previous work has shown that dII does not play a role in positioning the AUG in the P-site (Locker et al. 2007), our results may indicate that the mRNA is placed less stably in the decoding groove when dIIb is mutated, allowing the reverse transcriptase to penetrate into the decoding groove. But, this effect is different from when dII is completely removed $(\Delta \mathrm{dII})$. The difference in toeprints between the dIIb mutants and $\Delta$ dII parallel the aforementioned difference in translation initiation efficiencies. Taken together, these results suggest a specific role for dIIb in stabilizing the coding RNA in the 40S subunit decoding groove upon subunit binding; our data suggest that this is independent of dII's other described roles. 
A

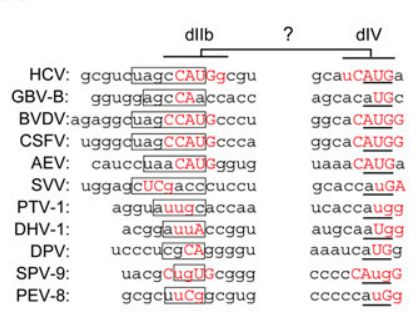

B

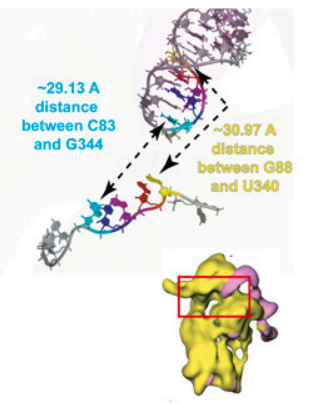

C

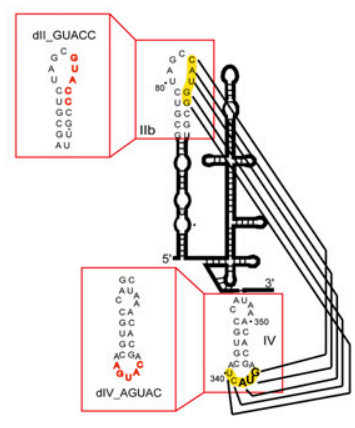

D
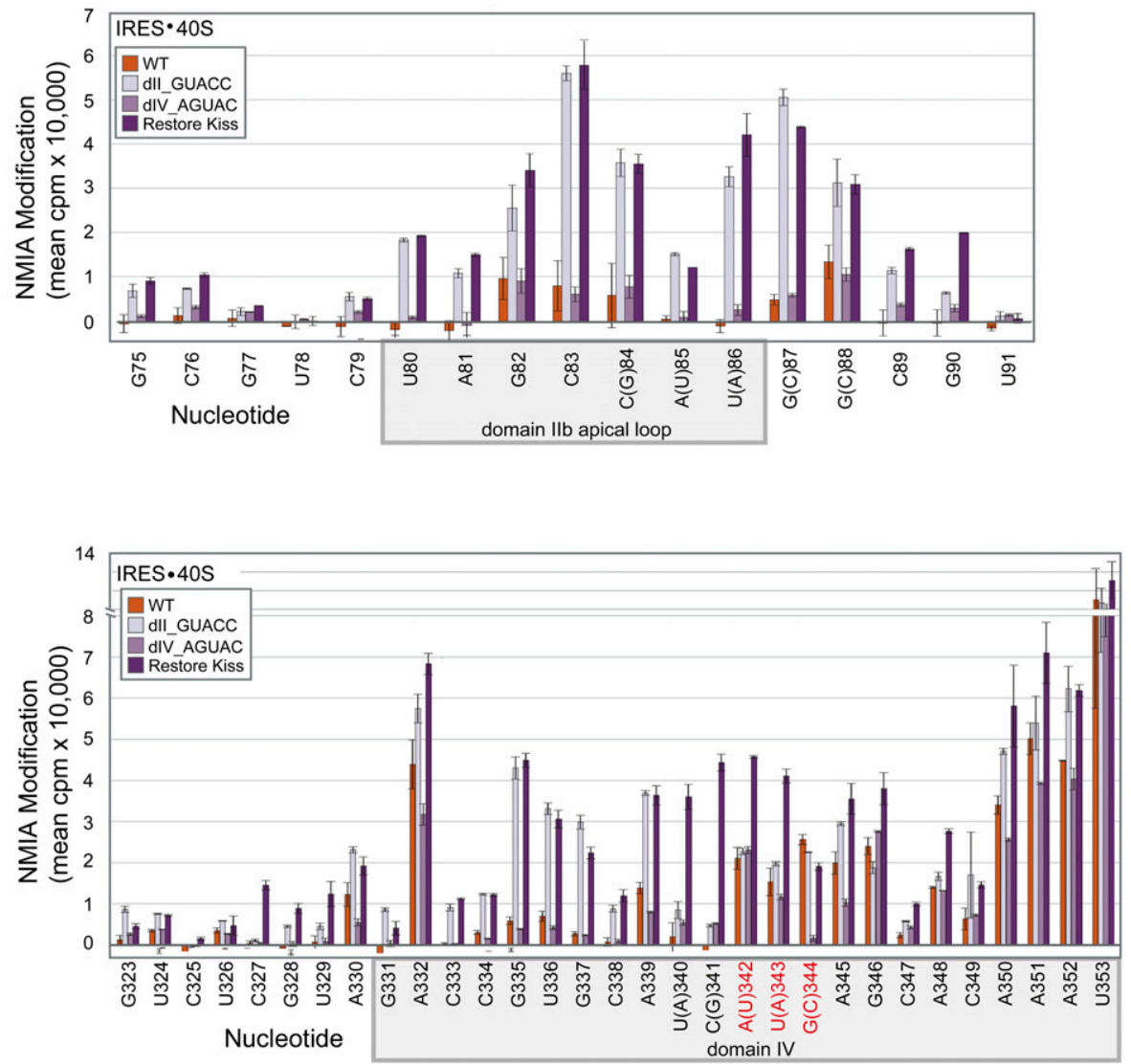

FIGURE 6. Investigation of possible base-pairing between domain IIb and domain IV. (A) Comparison of the sequences at the apical loop of domain II (dIIb) and the RNA in and around the AUG start codon (underlined) for 11 IRES RNAs proposed to have HCV-like secondary structures (Pestova and Hellen 1999; Hellen and de Breyne 2007). Boxes around parts of each sequence indicate the proposed location of the dIIb apical loop. Sequences were aligned based on the proposed position in each secondary structure. The possible base-pairing interaction in the HCV IRES is indicated with bars above the aligned sequences. In each sequence, red indicates stretches of two or more bases that could potentially pair (identified by visual examination). Uppercase red letters could form Watson-Crick pairs; lowercase could form $\mathrm{G} \bullet \mathrm{U}$ pairs. The pairing sequences, number of potential pairs, and location of these pairs is not conserved. (B) Model from Figure 3A with only the tip of domain II and the position of the mRNA and AUG in the P-site shown. The location of bases that could pair is shown with various colors; pairing partners have matching colors. The distance between potential pairing bases is shown. The cryo-EM reconstruction (Spahn et al. 2001) of the full-length IRES (magenta) bound to the $40 \mathrm{~S}$ subunit (yellow) is inset for reference. The part of the cryo-EM shown in the model is boxed in red. (C) Cartoon of HCV IRES secondary structure with mutations made in dIIb and dIV highlighted in red, and the putative base-pairing interaction indicated by lines connecting the two domains and yellow shading. AUG is indicated at the apex of dIV. (D) Quantitated, normalized, and background-corrected modification data from two independent SHAPE probing experiments of the WT IRES RNA and the mutants shown in $C$, all bound to the 40S subunit, with error bars representing one standard deviation from the mean of both. Note that the additional repeat for both the unbound and the IRES $\bullet 40 S$ bound state (data not shown) validates the quantitated data shown here. The degree of modification is on the $y$-axis; each nucleotide is on the $x$-axis, with the start codon AUG colored red and the location of domain IV indicated. Orange bars indicate WT IRES; bars in different shades of purple indicate mutants. The top graph contains the modifications for each RNA in the dIIb apical loop region; the bottom graph contains a comparison of modifications on each RNA in the dIV region. The start codon AUG is indicated in red. 


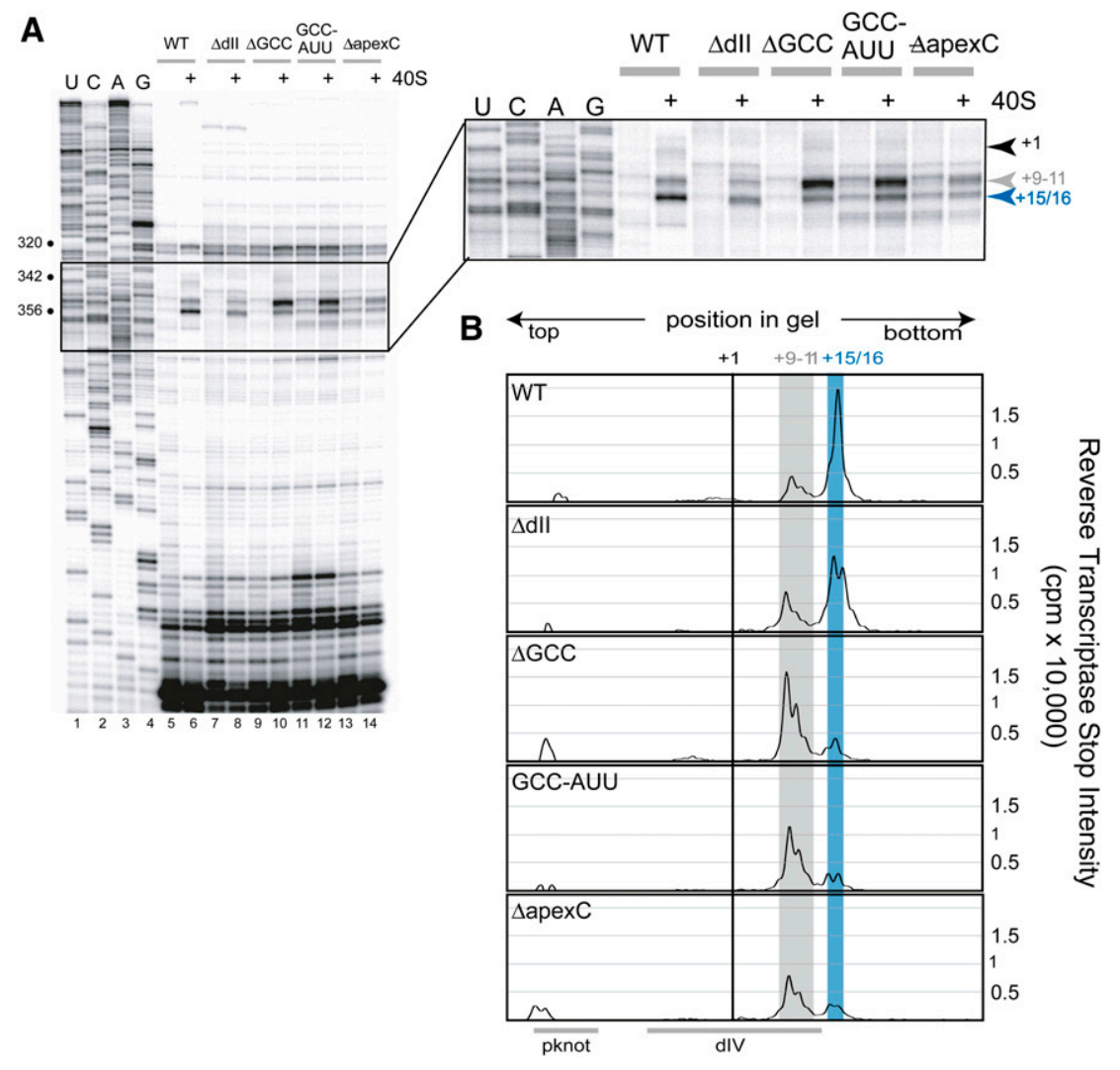

FIGURE 7. Toeprinting analysis of WT and mutant IRES RNAs. (A) Toeprinting gel of all mutants in the free form and bound to the 40S subunit. The relevant part of this gel is boxed and expanded to the right. The location of the A in the AUG is indicated as the +1 position, and stops at the $+9-11$ position and at location $+15 / 16$ are indicated by arrows to the right of the expanded gel region. $(B)$ Quantitated, background-corrected, and graphed toeprints of IRES•40S from the gel in $A$. Location +1 (AUG) is indicated by the black line, the +16 toeprint by the blue, and the $+9-11$ by the gray line. The location of IRES secondary structural regions is shown beneath the graphs.

\section{DISCUSSION}

In contrast to canonical cap- and scanning-dependent translation, proper assembly of the translation apparatus by the HCV IRES directly at the start codon is driven by specific IRES RNA structural domains working in a coordinated manner (for review, see Fraser and Doudna 2007; Lukavsky 2009). Studies continue to identify roles of different domains, and it is now clear that the IRES RNA is not just a binding site for the translational machinery, but that it manipulates the machinery and drives specific steps in initiation. Here, we report our discovery that dIV of the HCV IRES (which contains the start codon) unwinds and forms a specific configuration in the decoding groove upon binding to the $40 \mathrm{~S}$ subunit. Furthermore, we find that this configuration is dependent on the integrity of the tip of $\mathrm{dII}$, and this is correlated with the ability of the IRES to initiate translation.

Prompted by the discovery that another IRES RNA (the intergenic region IRES from the Dicistroviridae) un- dergoes structural changes upon binding to the $40 \mathrm{~S}$ subunit (Costantino et al. 2008; Pfingsten et al. 2010), we explored the hypothesis that the HCV IRES also undergoes functionally important structural changes upon $40 \mathrm{~S}$ subunit binding. Using chemical probing, we observed changes in the conformation of the RNA surrounding the initiation codon when the 40S subunit bound, the first step of the HCV IRES initiation mechanism. Specifically, binding to the HCV IRES destabilizes the dIV stem-loop that contains the AUG initiation codon as well as the first $\sim 14 \mathrm{nt}$ of the viral open reading frame. The fact that the dIV stem-loop must open and dock into the decoding groove is not in itself surprising, as the lack of ribosome scanning mandates that the HCV start codon and adjacent RNA dock directly into the decoding groove (Reynolds et al. 1996), and this would not be possible if the dIV stem-loop remained base-paired. However, ours is the first direct observation of this event occurring at the initial $40 S$ subunit binding step. Destabilization of the dIV stem-loop at this early step is likely important to facilitate recognition of the start codon and subsequent binding of the eIF2・Met-tRNA ${ }_{i}{ }^{\text {Met }} \cdot$ GTP ternary complex. Consistent with this, previous studies have shown that mutations predicted to destabilize dIV correlate with a slight increase in HCV translation initiation (Honda et al. 1996).

The fact that dIV destabilization is promoted by initial $40 \mathrm{~S}$ subunit binding presents the question of how this occurs. Direct interactions between the decoding groove and the HCV RNA in the groove likely favor singlestranded RNA binding, and these likely stabilize an unwound conformation of dIV. Given that the dIV stem-loop has previously been shown to be relatively unstable (Kieft et al. 1999), these direct HCV RNA-40S subunit interactions may be enough to shift equilibrium toward the unwound state. Also, ribosomal proteins S2 and S3, whose bacterial homologs have been identified as helicases (Yusupova et al. 2001) cross-link to the HCV IRES RNA (Otto et al. 2002) as well as to eukaryotic mRNAs 11-nt downstream from the start codon (Pisarev et al. 2008); thus, although our data does not address this, these proteins could be involved. Regardless of the mechanism, our data suggests that immediately after initial $40 \mathrm{~S}$ subunit binding, the HCV RNA in the decoding groove adopts a specific configuration that 
makes the AUG available for recognition by the eIF2•MettRNA $_{i}{ }^{\text {Met }} \cdot$ GTP ternary complex.

Perhaps our most intriguing observation is that upon binding to the $40 \mathrm{~S}$ subunit, dIV not only unwinds, but the RNA around the start codon assumes a stable configuration within the decoding groove, especially in the regions of the RNA between the pseudoknot and the AUG start codon. This configuration is stable and specific enough that it is protected from modification by SHAPE probing. There are likely a set of particular interactions that occur between this part of the HCV RNA and the decoding groove that lead to this specific configuration. In fact, studies of canonical mRNA-ribosome interactions reveal many interactions between the mRNA and the ribosome in the decoding groove (Pisarev et al. 2008) in both bacterial and eukaryotic ribosomes; therefore, it is likely these same interactions occur with the HCV RNA. Interestingly, we note that the part of the RNA upstream of the AUG, which we have shown to be stably configured in the decoding groove, is where the Kozak sequence is located in eukaryotic mRNAs translated by a scanning mechanism (Kozak 1986). Although scanning does not occur on the HCV IRES, it is intriguing to speculate that the RNA upstream of the HCV AUG is acting in some way analogously to the Kozak sequence. However, because the precise structural mechanism that underlies the action of the Kozak sequence is not understood, we cannot propose how this might be mimicked by the IRES. Furthermore, although it represents a very different system, in bacterial trans-translation the RNA just upstream of the "resume" codon is important for setting the transfermessenger RNA (tmRNA) reading frame into place, due to recognition by the decoding groove (Lim and Garber 2005; Miller et al. 2008). Thus, although the purpose or mechanism used by the RNA upstream of the AUG may be different than in these diverse systems, there clearly is a precedent of RNA upstream of initiation codons interacting with the ribosome in a specific and important way; the HCV IRES represents another important example.

We find that initial $40 \mathrm{~S}$ subunit binding is sufficient to destabilize dIV, but we have also found that it is not sufficient to form the specific configuration of the $\mathrm{HCV}$ RNA in the decoding groove. Rather, our probing shows that the configuration can be disrupted by IRES mutations to the tip of domain II (dIIb). Likewise, in conjunction with previous findings (Odreman-Macchioli et al. 2001; Kalliampakou et al. 2002; Otto and Puglisi 2004), these same mutations decrease the ability of the IRES to initiate translation. Thus, our results suggest that dIIb affects translation initiation due to its role in the configuration of the HCV RNA in the decoding groove. The fact that mutations to dIIb alter the configuration of the HCV RNA in the decoding groove just upstream of the AUG presents the question: What is the nature and consequence of this alteration? One possibility is that the position of the AUG start codon is incorrect when IIb is mutated and the configuration of the RNA upstream of the AUG is altered. Evidence for this is found in our toeprinting assays of WT and mutant IRES•40S complexes. In addition, recent biochemical and modeling studies report that the pseudoknot structure upstream of dIV plays a role in properly positioning the start codon in the P-site (Berry et al. 2010; Lavender et al. 2010) and, thus, there is a precedent for the structure of RNA upstream of the HCV AUG affecting its location. However, Locker et al. (2007) showed by crosslinking that complete removal of dII (mutant $\Delta \mathrm{dII}$ ) does not appear to affect the AUG-tRNA anticodon interaction in the P-site (Locker et al. 2007) (although there are some alterations to the toeprint). If $\Delta \mathrm{dII}$ still allows AUG docking in the P-site, it seems unlikely that mutation of just the apical loop of dII would prevent this docking. But, we do observe a different toeprint pattern when $\Delta \mathrm{dII}$ and the dIIb mutants are compared and these data suggest that they do have different effects on the placement and recognition of the AUG codon. The full nature of the effect of dIIb on the structure of the HCV RNA in the decoding groove, the AUG start codon, and the function of the IRES is the subject of an ongoing investigation.

Our discovery that dIIb promotes adoption of a specific HCV RNA configuration in the decoding groove and is necessary for full HCV IRES translation initiation activity adds to the known roles of dII. Previously defined roles of dII include the removal of eIF3j prior to subunit joining, and GTP hydrolysis by eIF2 (Locker et al. 2007; Fraser et al. 2009). Both of these steps occur after $48 S^{*}$ formation, and are therefore important for promoting formation of the $80 \mathrm{~S}$ subunit. Whether or not the new role of the very tip of dII (dIIb) is related to these roles or is distinct remains to be explored. But, given the fact that many effects induced by mutating dIIb are different from those observed when dII is removed entirely (i.e., SHAPE probing, toeprinting, translation initiation levels), it is possible that these dIIb roles are distinct from previously reported dII functions.

Ongoing functional and structural studies of the HCV IRES continue to reveal layers of mechanistic complexity. Thus, although this IRES and many other IRESs use fewer initiation factors to begin translation, it may not be accurate to describe their mechanism as "simpler" than the canonical pathway. Our discoveries of additional events important for HCV translation support the view of IRESs as dynamic manipulators of the translation machinery that may have the ability to lend insight into how the machinery works in both cap-dependent and cap-independent pathways.

\section{MATERIALS AND METHODS}

\section{Plasmid construction and cloning}

The construction of pUC19-based plasmids containing the HCV genotype Ib wild-type (nucleotides 40-372) and $\Delta$ dII mutant (nucleotides 119-372) sequences flanked by a 5' hammerhead and 
$3^{\prime}$ hepatitis $\delta$ ribozymes were described previously (Kieft et al. 1999, 2001). Mutants were generated using the QuickChange mutagenesis kit (Stratagene). Plasmids with the WT or mutant HCV IRES between two luciferase genes were constructed by PCR amplification of the desired sequence from these plasmids, and then ligation into the EcoR1 and NcoI sites of plasmid pRL (kind gift of A.E. Willis) (Stoneley et al. 1998). The plasmid used to generate RNA for the toeprinting analysis (contains 85 additional $3^{\prime} \mathrm{nt}$ on the wildtype HCV genotype $1 \mathrm{a}$, as well as the primer binding site) was a kind gift of P.J. Lukavsky (Locker et al. 2007). The genotype 1b $\Delta$ dII mutant used in toeprinting was generated by PCR amplification of the desired sequence and ligation into the Hind III/XbaI site of this plasmid, and subdomain IIb mutants were generated using the QuickChange mutagenesis kit (Stratagene).

\section{RNA preparation}

RNAs for SHAPE and T1 footprinting were made using DNA generated by PCR using M13-41 forward and reverse primers (5'-GGTTTTCCCAGTCACGAC-3' and 5'-GGAAACAGCTATGA CCATG-3', respectively) and the relevant pUC19-based plasmid template. The PCR products were used for in vitro transcription reactions as previously described (Keel et al. 2007). RNA was purified on 10\% acrylamide (29:1 bisacrylamide:acrylamide) $7 \mathrm{M}$ ureadenaturing gels. Bands were identified by UV shadowing, excised, eluted in RNase-free water overnight at $4^{\circ} \mathrm{C}$, then concentrated and washed using Amicon Ultra filters (Millipore). Monocistronic Photinus luciferase RNAs were made from PCR templates using forward T7-HCV and reverse photinus primers ( $5^{\prime}$-TAATACGACTCACTA TAGGGCTCCCCTGTGAGGAACTACTGTCTT- $3^{\prime}$ and $5^{\prime}$-TTACACG GCGATCTTTCCGCCCTTCTT-3', respectively). RNAs were DNase treated, then purified with TRI Reagent (Sigma) and chloroform, followed by isopropanol, $100 \%$ and $75 \%$ ethanol precipitations, respectively. RNAs for toeprinting were made from EcoR1-linearized plasmids in the same manner as the luciferase RNAs.

\section{Radiolabeling RNA and primers}

RNA was $5^{\prime}$-radiolabeled in a reaction containing $4 \mu \mathrm{g}$ of purified RNA, $2 \mu \mathrm{L}$ of $10 \mathrm{X}$ polynucleotide kinase (PNK) buffer $(70 \mathrm{mM}$ Tris- $\mathrm{HCl}$ at $\mathrm{pH} 7.6,10 \mathrm{mM} \mathrm{MgCl}_{2}, 5 \mathrm{mM}$ DTT, New England Biolabs), $2 \mu \mathrm{L}$ of T4 PNK (10,000 U/mL, NEB), $1 \mu \mathrm{L}$ of $\left[\gamma^{32} \mathrm{P}\right] \mathrm{ATP}$ (Perkin Elmer or MP Biomedicals, $6000 \mathrm{Ci} / \mathrm{mmol}$ ) in a final volume of $20 \mu \mathrm{L}$. Reactions were incubated at $35^{\circ} \mathrm{C}$ for $1 \mathrm{~h}$ and then spun through Micro Bio-Spin 30 Tris Chromatography Columns (BioRad). A total of $10 \mu \mathrm{L}$ of $9 \mathrm{M}$ urea loading buffer was added and the reactions were loaded on a $10 \%$ acrylamide (29:1 bisacrylamide:acrylamide) $7 \mathrm{M}$ urea-denaturing gel (16.5 $\mathrm{cm} \times 25 \mathrm{~cm} \times 1 \mathrm{~mm}$ ) and electrophoresed at $25 \mathrm{~W}$ for $\sim 30 \mathrm{~m}$. RNAs were visualized by autoradiography, and bands were excised and eluted in Elution Buffer (0.5 M NaOAC at pH 5.3, $0.1 \%$ SDS) overnight, followed by ethanol precipitation, then dissolved in RNAse-free water prior to use. Body-labeled Monocistronic Photinus luciferase RNAs were created using PCR products (primers indicated above) as transcription templates using the Promega Riboprobe transcription kit. Kit conditions were used for $20 \mu \mathrm{L}$ reactions along with $50 \mu \mathrm{Ci}$ of $\left[\alpha-{ }^{32} \mathrm{P}\right] \mathrm{UTP}$ (Perkin Elmer, $800 \mathrm{Ci} / \mathrm{mmol}$ ) per reaction for $2 \mathrm{~h}$ at $30^{\circ} \mathrm{C}$. Completed transcription reactions were treated with kit DNase for $15 \mathrm{~min}$ at $37^{\circ} \mathrm{C}$, mixed with $30 \mu \mathrm{L}$ of $20 \mathrm{mM}$ EDTA and separated from unincorporated nucleotides via size-exclusion chromatography (G50 columns, GE Healthcare). Purity and counts per minute were analyzed by electrophoresis on an $8 \%$ ureadenaturing gel (described above) at $30 \mathrm{~W}$ for $1.5 \mathrm{~h}$, followed by autoradiography and liquid scintillation, respectively.

DNA primers were $5^{\prime}$-radiolabeled in a reaction containing 800 pmol DNA primer in the same conditions as above, but were not passed through the spin columns. Rather, they were mixed with $20 \mu \mathrm{L}$ of $9 \mathrm{M}$ urea loading buffer, loaded directly onto a $10 \%$ urea denaturing gel, and purified as described above.

\section{SHAPE}

For SHAPE, 16 pmol of RNA in $24 \mu \mathrm{L}$ of RNase-free water was heated to $85^{\circ} \mathrm{C}$ for $30 \mathrm{sec}$, then cooled on the desktop. A total of $12 \mu \mathrm{L}$ of RNA folding buffer (333 mM HEPES at pH 8.0, $20 \mathrm{mM}$ $\mathrm{MgCl}_{2}, 333 \mathrm{mM} \mathrm{NaCl}$ ) was added, and for the $+40 \mathrm{~S}$ samples, 16 pmol of purified $40 \mathrm{~S}$ ribosomal subunits were added. $40 \mathrm{~S}$ subunits were prepared as described in Kieft et al. (2001). One microliter of DMSO was added to the DMSO controls and $1 \mu \mathrm{L}$ of $389 \mathrm{mM}$ $\mathrm{N}$-methylisatoic anyhydride (NMIA) prepared in DMSO was added to the experimental reactions. Reactions were incubated at $35^{\circ} \mathrm{C}$ for $1 \mathrm{~h}$, then desalted using Micro Bio-Spin 30 Tris Chromatography Columns (BioRad) and brought up to a $10-\mu \mathrm{L}$ volume using RNase-free water. Reverse transcription (RT) was done with $1 \mu \mathrm{L}$ of one of the following primers: Full-length RT primer

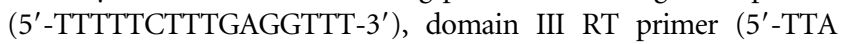
ATCCAAGAAAGGACCCGG-3'), or domain II RT primer (5'-GGG TCCTGGAGGCTGCAC- $3^{\prime}$ ), which were $5^{\prime}$-end labeled with ${ }^{32} \mathrm{P}$ and diluted to $25,000 \mathrm{cpm} / \mu \mathrm{L}$. RT reactions for full-length $\mathrm{RT}$ and domain III RT were as follows: initial denaturation at $75^{\circ} \mathrm{C}$ for 5 min, primer annealing at $37^{\circ} \mathrm{C}$ for $20 \mathrm{~min}$. RT buffer $(1.67 \mathrm{mM}$ each dNTP, $167 \mathrm{mM}$ Tris- $\mathrm{HCl}$ at $\mathrm{pH} 8.3,250 \mathrm{mM} \mathrm{KCl}, 10 \mathrm{mM}$ $\mathrm{MgCl}_{2}$ and $17 \mathrm{mM}$ DTT) was added to DMSO/NMIA reaction tubes, while the ladder was made with similar buffer, except 0.15 $\mathrm{mM}$ dNTP in combination with $2.5 \mathrm{mM}$ ddNTP of the relevant ddNTP. Reactions were equilibrated at $37^{\circ} \mathrm{C}$ for $1 \mathrm{~min}$ and then $0.5 \mu \mathrm{L}$ of SuperScript Reverse Transcriptase $(200 \mathrm{U} / \mu \mathrm{L}$, Invitrogen) was added for extension at $37^{\circ} \mathrm{C}$ for $10 \mathrm{~min}$. Reactions were halted by the addition of $1 \mu \mathrm{L}$ of $4 \mathrm{M} \mathrm{NaOH}$ to hydrolyze the RNA at $95^{\circ} \mathrm{C}$ for $5 \mathrm{~min}$, followed by the addition of Acid Stop Mix (4:25 v/v mixture of $1 \mathrm{M}$ unbuffered Tris- $\mathrm{HCl}$ and $29 \mu \mathrm{L}$ Stop Dye [85\% formamide, 0.5X TBE, $50 \mathrm{mM}$ EDTA at $\mathrm{pH}$ 8.0, bromophenol blue and xylene cyanol]) at $95^{\circ} \mathrm{C}$ for $5 \mathrm{~min}$. For RT reactions using the domain II RT primer, everything was done identically, except that all temperatures at $37^{\circ} \mathrm{C}$ were carried out at $50^{\circ} \mathrm{C}$. Seven microliters of each $\mathrm{RT}$ reaction was run on a $10 \%$ acrylamide (29:1 bisacrylamide:acrylamide) $7 \mathrm{M}$ urea denaturing sequencing gel $(35 \mathrm{~cm} \times 45 \mathrm{~cm} \times 0.4 \mathrm{~mm})$ at $65 \mathrm{~W}$, dried, and exposed to phosphorscreen for $12 \mathrm{~h}$. Gels were aligned using the Semi-Automated Footprinting Analysis (SAFA) software (Das et al. 2005), and output files were then normalized to total radiation in each lane (determined using ImageQuant Software), followed by background subtraction of the DMSO only lanes in Microsoft Xcel. The data was graphed in KaleidaGraph.

\section{T1 footprinting}

RNase T1 probing was carried out essentially as described (Kieft et al. 2001). Briefly, radiolabeled HCV IRES RNAs $(10,000 \mathrm{cpm} / \mu \mathrm{L})$ 
were heated to $85^{\circ} \mathrm{C}$ for $30 \mathrm{sec}$ and then cooled on the desktop. One microliter of this RNA was then combined with $30 \mathrm{mM}$ HEPES-KOH ( $\mathrm{pH} 7.5$ ) and $2.5 \mathrm{mM} \mathrm{MgCl}_{2}$ in a final volume of $10 \mu \mathrm{L}$. For $+40 \mathrm{~S}$ reactions, $24.5 \mathrm{pmol}$ of purified $40 \mathrm{~S}$ ribosomal subunits were added. All reactions were incubated at $37^{\circ} \mathrm{C}$ for 5 min to reach folding/binding equilibrium. One microliter of a 0.1 $\mathrm{U} / \mu \mathrm{L}$ dilution of RNase T1 (Roche) was added to each tube and incubated for $5 \mathrm{~min}$ at $37^{\circ} \mathrm{C}$. Reactions were halted with the addition of $2 \mu \mathrm{g}$ of Arabadopsis thaliana tRNA and $10 \mu \mathrm{L}$ of RNase-free water, followed by addition of an equal volume of phenol-chloroform, isoamyl alcohol (PCIAA), and placed on ice. RNAs were extracted, followed by a second 24:1 chloroform: isoamyl alcohol (CIAA) extraction, and precipitated with $3 \mathrm{~V}$ $100 \%$ cold ethanol and $1 / 10$ th $\mathrm{V}$ of $3 \mathrm{M} \mathrm{NaOAc}(\mathrm{pH} 5.2$ ) overnight at $-20^{\circ} \mathrm{C}$, pelleted, then washed with $70 \%$ ethanol. Pellets were dried and resuspended in $4.5 \mathrm{M}$ urea loading dye, heated to $55^{\circ} \mathrm{C}$ for $1 \mathrm{~min}$, and resolved by electrophoresis through a sequencing gel as described above. The T1 Ladder was generated by mixing $3 \mu \mathrm{L}$ of $\mathrm{T} 1$ buffer $(20 \mathrm{mM}$ sodium citrate at $\mathrm{pH}$ 5.0, $1 \mathrm{mM}$ EDTA, $7 \mathrm{M}$ urea) with $1 \mu \mathrm{g}$ of tRNA and $1 \mu \mathrm{L}$ of radiolabeled HCV IRES RNA. This reaction was incubated at $55^{\circ} \mathrm{C}$ for $1 \mathrm{~min}$, then $0.1 \mathrm{U} / \mu \mathrm{L}$ of RNase $\mathrm{T} 1$ was added for a 3-min incubation at $55^{\circ} \mathrm{C}$, followed by the addition of $15 \mu \mathrm{L}$ of $9 \mathrm{M}$ urea loading buffer. The hydrolysis $(\mathrm{OH})$ ladder was generated by mixing $1 \mu \mathrm{L}$ of hydrolysis buffer $(500 \mathrm{mM} \mathrm{NaHCO}$ at $\mathrm{pH} 9.2$ ) with $1 \mu \mathrm{g}$ of tRNA and $1 \mu \mathrm{L}$ of radiolabeled RNA in a final volume of $10 \mu \mathrm{L}$. The reaction was incubated at $85^{\circ} \mathrm{C}$ for $5 \mathrm{~min}$ and was quenched with the addition of $10 \mu \mathrm{L}$ of $9 \mathrm{M}$ urea loading buffer.

\section{Luciferase assays}

To analyze the amount and quality of input RNA, $1 \mu \mathrm{g}$ of each monocistronic luciferase RNA was run on a $6 \%$ urea denaturing gel $(16.5 \mathrm{~cm} \times 25 \mathrm{~cm} \times 1 \mathrm{~mm})$ and electrophoresed at $25 \mathrm{~W}$. The gel was then stained with ethidium bromide and bands were visualized via UV light. Band intensities were quantified using ImageQuant software.

Translation assays were prepared by mixing the following reagents: $17.5 \mu \mathrm{L}$ of RRL (Promega), $0.25 \mu \mathrm{L}$ of amino acid mixture minus methionine, and $0.25 \mu \mathrm{L}$ of amino acid mixture minus leucine (Promega), $110 \mathrm{mM} \mathrm{KCl}$ and $0.5 \mathrm{mM} \mathrm{MgCl}_{2}$ (optimal salt concentrations for $\mathrm{HCV}$ translation initiation as suggested by Borman et al. 1995), and $0.5 \mu \mathrm{g}$ of monocistronic RNA in a final volume of $25 \mu \mathrm{L}$. Reactions were incubated at $30^{\circ} \mathrm{C}$ for $90 \mathrm{~min}$, and halted by the addition of $200 \mu \mathrm{L}$ of cold $1 \mathrm{X}$ Passive Lysis Buffer (Promega), and then placed on ice. A total of $20 \mu \mathrm{L}$ of the diluted translation reaction was mixed (by pipetting) with $100 \mu \mathrm{L}$ of Luciferase Assay Reagent II, and luciferase readings were carried out using the Berthold Detection Systems luminometer (Sirius).

\section{Degradation assays}

Translation assays were conducted as indicated above, but supplemented with $50 \mathrm{ng}\left[\alpha-{ }^{32} \mathrm{P}\right]$-labeled monocistronic RNA per reaction and increased reaction volume for extraction at various time points. For the degradation experiment, $12.5 \mu \mathrm{L}$ of the translation reaction was extracted at $0,15,30,60$, and 90 min and supplemented with water to a final volume of $50 \mu \mathrm{L}$ for PCIAA extraction. Extracted RNA was precipitated with 1/10th V $3 \mathrm{M}$
$\mathrm{NaOAc}\left(\mathrm{pH} 5.2\right.$ ) and $3 \mathrm{~V}$ cold $100 \%$ ethanol at $-80^{\circ} \mathrm{C}$ for $2.5 \mathrm{~h}$. Precipitations were pelleted at $4^{\circ} \mathrm{C}, 14,000 \mathrm{rpm}$ for $30 \mathrm{~min}$, and resuspended in $4.5 \mathrm{M}$ urea loading dye to have similar $\mathrm{cpm} / \mu \mathrm{L}$, and equal volumes were electrophoresed on a $7 \mathrm{M}$ urea, $8 \%$ acrylamide (29:1 acrylamide:bisacrylamide) gel $(16.5 \mathrm{~cm} \times 25 \mathrm{~cm} \times 1 \mathrm{~mm})$ at $30 \mathrm{~W}$ for $1.5 \mathrm{~h}$. Gels were dried overnight $\left(50^{\circ} \mathrm{C}\right.$ heat for $\left.3 \mathrm{~h}\right)$ and exposed to a phosphorscreen for quantitation.

\section{Toeprinting assays}

Toeprinting assays were adapted from published techniques (Pestova et al. 1996; Wilson et al. 2000; Locker et al. 2007). For unbound IRES: $0.5 \mu \mathrm{g}$ of each toeprint RNA was mixed with 13.5 $\mu \mathrm{L}$ of Buffer A (20 mM Tris at pH 7.5, $100 \mathrm{mM} \mathrm{KOAc,} 2.5 \mathrm{mM}$ MgOAc, $2 \mathrm{mM}$ DTT, $1 \mathrm{mM}$ ATP, $0.25 \mathrm{mM}$ spermidine) and 0.5 $\mu \mathrm{L}$ of RNasin Plus (40 U/ $\mu \mathrm{L}$, Promega) in a final volume of 15 $\mu \mathrm{L}$. For 40S-bound IRES: $0.5 \mu \mathrm{g}$ of RNA was mixed with $12.5 \mu \mathrm{L}$ of Buffer A, $0.5 \mu \mathrm{L}$ of RNasin Plus, and $\sim 8$ pmol of purified $40 \mathrm{~S}$ ribosomal subunits. All reactions were incubated at $30^{\circ} \mathrm{C}$ for 5 min to allow binding/folding equilibrium, followed by addition of Buffer A up to $40 \mu \mathrm{L}$ volume and addition of $1 \mu \mathrm{L}$ of toeprint primer (5'-GGGATTTCTGATCTCGGCG-3', 25,000 cpm/ $\mu \mathrm{L}$ ). All reactions were again incubated at $30^{\circ} \mathrm{C}$ for $5 \mathrm{~min}$ to allow primer annealing, followed by the addition of $4 \mu \mathrm{L}$ of dNTP mixture ( $5 \mathrm{mM}$ each of dATP, dCTP, dGTP, and dTTP), $1 \mu \mathrm{L}$ of $320 \mathrm{mM}$ $\mathrm{MgOAc}$, and $0.5 \mu \mathrm{L}$ of avian myeloblastosis virus reverse transcriptase (AMV-RT, $25 \mathrm{U} / \mu \mathrm{L}$, Promega). Reactions were incubated at $30^{\circ} \mathrm{C}$ for $45 \mathrm{~min}$ and quenched with $4 \mu \mathrm{L}$ of $4 \mathrm{M} \mathrm{NaOH}$ and heated to $85^{\circ} \mathrm{C}$ for $5 \mathrm{~min}$ to hydrolyze RNA. Reactions were extracted using PCIAA, followed by an additional CIAA extraction, and precipitated overnight at $-20^{\circ} \mathrm{C}$ using $3 \mathrm{~V}$ cold $100 \%$ ethanol and 1/10th V $3 \mathrm{M} \mathrm{NaOAc}$ ( $\mathrm{pH}$ 5.2). Pellets were resuspended in 4.5 $\mathrm{M}$ urea loading dye to have similar $\mathrm{cpm} / \mu \mathrm{L}$, and equal volumes were electrophoresed on a sequencing gel as described above. The ladder used for analysis was made using wild-type toeprint RNA reverse transcribed with SuperScript III Reverse Transcriptase as described above with annealing and extension temperatures at $45^{\circ} \mathrm{C}$.

\section{Modeling the position of domain II on the 40S subunit}

The NMR structure of HCV IRES domain II (Lukavsky et al. 2003) was visually modeled into the cryo-electron microscopy map of the full-length IRES bound to the rabbit 40 S subunit and with the generous advice of Christian Spahn (Spahn et al. 2001). Domain II (specifically around IIa) does not completely fit the cryo-EM density because the NMR structure was not solved in context of the IRES•40S complex; in fact, that region of the IRES bends in order to lay flat against the solvent side of the $40 \mathrm{~S}$ subunit (CM Spahn, pers. comm.). However, the dIIb portion was readily fit into the density. The crystal structure of the Tetrahymena thermophila 40S subunit (Rabl et al. 2011) and the crystal structure of the $30 \mathrm{~S}$ subunit+mRNA (extracted from a structure off the 70S ribosome with all tRNAs and mRNA) (Selmer et al. 2006) were manually positioned into the cryo-EM structure of the unbound rabbit 40 S subunit (Spahn et al. 2001). The two crystal structures were aligned to maximize overlap in the decoding groove region, particularly the rRNA. The overall model has little or no steric clash between domain II and the ribosome structure, and matches the cryo-EM density quite well. 


\section{ACKNOWLEDGMENTS}

We thank Drs. Richard Davis, David Barton, and Tom Evans for critical reading of the manuscript and insightful comments, current and former Kieft Lab members for thoughtful discussions and technical assistance, P.J. Lukavsky and A.E. Willis for plasmids used in this study, and C.M.T. Spahn for examination of our structural model. This work was supported by NIH grant GM08134603 and American Cancer Society Research Scholar Grant RSG0805801 to J.S.K. M.E.F. was an American Heart Association predoctoral fellow (\#0815655G). J.S.K. is an Early Career Scientist of the Howard Hughes Medical Institute.

Received December 15, 2010; accepted April 18, 2011.

\section{REFERENCES}

Babaylova E, Graifer D, Malygin A, Stahl J, Shatsky I, Karpova G. 2009. Positioning of subdomain IIId and apical loop of domain II of the hepatitis C IRES on the human 40 S ribosome. Nucleic Acids Res 37: 1141-1151.

Berry KE, Waghray S, Doudna JA. 2010. The HCV IRES pseudoknot positions the initiation codon on the 40 S ribosomal subunit. RNA 16: $1559-1569$.

Borman AM, Bailly JL, Girard M, Kean KM. 1995. Picornavirus internal ribosome entry segments: comparison of translation efficiency and the requirements for optimal internal initiation of translation in vitro. Nucleic Acids Res 23: 3656-3663.

Brown EA, Zhang H, Ping LH, Lemon SM. 1992. Secondary structure of the $5^{\prime}$ nontranslated regions of hepatitis $C$ virus and pestivirus genomic RNAs. Nucleic Acids Res 20: 5041-5045.

Collier AJ, Gallego J, Klinck R, Cole PT, Harris SJ, Harrison GP, AboulEla F, Varani G, Walker S. 2002. A conserved RNA structure within the HCV IRES eIF3-binding site. Nat Struct Biol 9: 375-380.

Costantino DA, Pfingsten JS, Rambo RP, Kieft JS. 2008. tRNA-mRNA mimicry drives translation initiation from a viral IRES. Nat Struct Mol Biol 15: 57-64.

Das R, Laederach A, Pearlman SM, Herschlag D, Altman RB. 2005. SAFA: semi-automated footprinting analysis software for highthroughput quantification of nucleic acid footprinting experiments. RNA 11: 344-354.

de Breyne S, Yu Y, Pestova TV, Hellen CU. 2008. Factor requirements for translation initiation on the Simian picornavirus internal ribosomal entry site. RNA 14: 367-380.

Dibrov SM, Johnston-Cox H, Weng YH, Hermann T. 2007. Functional architecture of HCV IRES domain II stabilized by divalent metal ions in the crystal and in solution. Angew Chem Int Ed Engl 46: 226-229.

Easton LE, Locker N, Lukavsky PJ. 2009. Conserved functional domains and a novel tertiary interaction near the pseudoknot drive translational activity of hepatitis $\mathrm{C}$ virus and hepatitis $\mathrm{C}$ virus-like internal ribosome entry sites. Nucleic Acids Res 37: 5537-5549.

Fraser CS, Doudna JA. 2007. Structural and mechanistic insights into hepatitis C viral translation initiation. Nat Rev Microbiol 5: 29-38.

Fraser CS, Hershey JW, Doudna JA. 2009. The pathway of hepatitis C virus mRNA recruitment to the human ribosome. Nat Struct Mol Biol 16: 397-404.

Hellen CU. 2009. IRES-induced conformational changes in the ribosome and the mechanism of translation initiation by internal ribosomal entry. Biochim Biophys Acta 1789: 558-570.

Hellen CU, de Breyne S. 2007. A distinct group of hepacivirus/ pestivirus-like internal ribosomal entry sites in members of diverse picornavirus genera: evidence for modular exchange of functional noncoding RNA elements by recombination. J Virol 81: 5850-5863.

Honda M, Brown EA, Lemon SM. 1996. Stability of a stem-loop involving the initiator AUG controls the efficiency of internal initiation of translation on hepatitis C virus RNA. RNA 2: 955968.

Honda M, Beard MR, Ping LH, Lemon SM. 1999. A phylogenetically conserved stem-loop structure at the $5^{\prime}$ border of the internal ribosome entry site of hepatitis $\mathrm{C}$ virus is required for capindependent viral translation. J Virol 73: 1165-1174.

Ji H, Fraser CS, Yu Y, Leary J, Doudna JA. 2004. Coordinated assembly of human translation initiation complexes by the hepatitis C virus internal ribosome entry site RNA. Proc Natl Acad Sci 101: 16990-16995.

Kalliampakou KI, Psaridi-Linardaki L, Mavromara P. 2002. Mutational analysis of the apical region of domain II of the HCV IRES. FEBS Lett 511: 79-84.

Keel AY, Rambo RP, Batey RT, Kieft JS. 2007. A general strategy to solve the phase problem in RNA crystallography. Structure 15: 761-772.

Kieft JS, Zhou K, Jubin R, Murray MG, Lau JY, Doudna JA. 1999. The hepatitis $\mathrm{C}$ virus internal ribosome entry site adopts an iondependent tertiary fold. J Mol Biol 292: 513-529.

Kieft JS, Zhou K, Jubin R, Doudna JA. 2001. Mechanism of ribosome recruitment by hepatitis C IRES RNA. RNA 7: 194-206.

Kieft JS, Zhou K, Grech A, Jubin R, Doudna JA. 2002. Crystal structure of an RNA tertiary domain essential to HCV IRESmediated translation initiation. Nat Struct Biol 9: 370-374.

Klinck R, Westhof E, Walker S, Afshar M, Collier A, Aboul-Ela F. 2000. A potential RNA drug target in the hepatitis $C$ virus internal ribosomal entry site. RNA 6: 1423-1431.

Kolupaeva VG, Pestova TV, Hellen CU. 2000a. An enzymatic footprinting analysis of the interaction of $40 \mathrm{~S}$ ribosomal subunits with the internal ribosomal entry site of hepatitis C virus. J Virol 74: $6242-6250$

Kolupaeva VG, Pestova TV, Hellen CU. 2000b. Ribosomal binding to the internal ribosomal entry site of classical swine fever virus. $R N A$ 6: 1791-1807.

Kozak M. 1986. Point mutations define a sequence flanking the AUG initiator codon that modulates translation by eukaryotic ribosomes. Cell 44: 283-292.

Lafuente E, Ramos R, Martinez-Salas E. 2002. Long-range RNA-RNA interactions between distant regions of the hepatitis $C$ virus internal ribosome entry site element. J Gen Virol 83: 1113-1121.

Laletina E, Graifer D, Malygin A, Ivanov A, Shatsky I, Karpova G. 2006. Proteins surrounding hairpin IIIe of the hepatitis $C$ virus internal ribosome entry site on the human $40 \mathrm{~S}$ ribosomal subunit. Nucleic Acids Res 34: 2027-2036.

Lavender CA, Ding F, Dokholyan NV, Weeks KM. 2010. Robust and generic RNA modeling using inferred constraints: a structure for the hepatitis $C$ virus IRES pseudoknot domain. Biochemistry 49: 4931-4933.

Lim VI, Garber MB. 2005. Analysis of recognition of transfermessenger RNA by the ribosomal decoding center. J Mol Biol 346: 395-398.

Locker N, Easton LE, Lukavsky PJ. 2007. HCV and CSFV IRES domain II mediate eIF2 release during $80 \mathrm{~S}$ ribosome assembly. EMBO J 26: 795-805.

Lukavsky PJ. 2009. Structure and function of HCV IRES domains. Virus Res 139: 166-171.

Lukavsky PJ, Otto GA, Lancaster AM, Sarnow P, Puglisi JD. 2000. Structures of two RNA domains essential for hepatitis C virus internal ribosome entry site function. Nat Struct Biol 7: 1105-1110.

Lukavsky PJ, Kim I, Otto GA, Puglisi JD. 2003. Structure of HCV IRES domain II determined by NMR. Nat Struct Biol 10: 10331038.

Lytle JR, Wu L, Robertson HD. 2001. The ribosome binding site of hepatitis C virus mRNA. J Virol 75: 7629-7636.

Lytle JR, Wu L, Robertson HD. 2002. Domains on the hepatitis $\mathrm{C}$ virus internal ribosome entry site for 40 s subunit binding. $R N A$ 8: 1045-1055.

Merino EJ, Wilkinson KA, Coughlan JL, Weeks KM. 2005. RNA structure analysis at single nucleotide resolution by selective 
2 '-hydroxyl acylation and primer extension (SHAPE). J Am Chem Soc 127: 4223-4231.

Miller MR, Healey DW, Robison SG, Dewey JD, Buskirk AR. 2008. The role of upstream sequences in selecting the reading frame on tmRNA. BMC Biol 6: 29. doi: 10.1186/1741-7007-6-29.

Odreman-Macchioli F, Baralle FE, Buratti E. 2001. Mutational analysis of the different bulge regions of hepatitis $\mathrm{C}$ virus domain II and their influence on internal ribosome entry site translational ability. J Biol Chem 276: 41648-41655.

Otto GA, Puglisi JD. 2004. The pathway of HCV IRES-mediated translation initiation. Cell 119: 369-380.

Otto GA, Lukavsky PJ, Lancaster AM, Sarnow P, Puglisi JD. 2002. Ribosomal proteins mediate the hepatitis C virus IRES-HeLa 40S interaction. RNA 8: 913-923.

Passmore LA, Schmeing TM, Maag D, Applefield DJ, Acker MG, Algire MA, Lorsch JR, Ramakrishnan V. 2007. The eukaryotic translation initiation factors eIF1 and eIF1A induce an open conformation of the 40S ribosome. Mol Cell 26: 41-50.

Paulsen RB, Seth PP, Swayze EE, Griffey RH, Skalicky JJ, Cheatham TE 3rd, Davis DR. 2010. Inhibitor-induced structural change in the HCV IRES domain IIa RNA. Proc Natl Acad Sci 107: 7263-7268.

Pestova TV, Hellen CU. 1999. Internal initiation of translation of bovine viral diarrhea virus RNA. Virology 258: 249-256.

Pestova TV, Hellen CU, Shatsky IN. 1996. Canonical eukaryotic initiation factors determine initiation of translation by internal ribosomal entry. Mol Cell Biol 16: 6859-6869.

Pestova TV, Shatsky IN, Fletcher SP, Jackson RJ, Hellen CU. 1998. A prokaryotic-like mode of cytoplasmic eukaryotic ribosome binding to the initiation codon during internal translation initiation of hepatitis C and classical swine fever virus RNAs. Genes Dev 12: 67-83.

Pestova T, Lorsch JR, Hellen CU. 2007. The mechanism of translation initiation in eukaryotes. In Translational control in biology and medicine (ed. MB Mathews et al.), pp. 87-128. Cold Spring Harbor Laboratory Press, Cold Spring Harbor, NY.

Pestova TV, de Breyne S, Pisarev AV, Abaeva IS, Hellen CU. 2008. eIF2-dependent and eIF2-independent modes of initiation on the CSFV IRES: a common role of domain II. EMBO J 27: 1060-1072.

Pfingsten JS, Castile AE, Kieft JS. 2010. Mechanistic role of structurally dynamic regions in Dicistroviridae IGR IRESs. J Mol Biol 395: 205-217.

Pisarev AV, Chard LS, Kaku Y, Johns HL, Shatsky IN, Belsham GJ. 2004. Functional and structural similarities between the internal ribosome entry sites of hepatitis $\mathrm{C}$ virus and porcine teschovirus, a picornavirus. J Virol 78: 4487-4497.
Pisarev AV, Kolupaeva VG, Yusupov MM, Hellen CU, Pestova TV. 2008. Ribosomal position and contacts of mRNA in eukaryotic translation initiation complexes. EMBO J 27: 1609-1621.

Rabl J, Leibundgut M, Ataide SF, Haag A, Ban N. 2011. Crystal structure of the eukaryotic $40 \mathrm{~S}$ ribosomal subunit in complex with initiation factor 1. Science 331: 730-736.

Reynolds JE, Kaminski A, Carroll AR, Clarke BE, Rowlands DJ, Jackson RJ. 1996. Internal initiation of translation of hepatitis $C$ virus RNA: The ribosome entry site is at the authentic initiation codon. RNA 2: 867-878.

Rijnbrand R, Abell G, Lemon SM. 2000. Mutational analysis of the GB virus B internal ribosome entry site. J Virol 74: 773-783.

Selmer M, Dunham CM, Murphy FV 4th, Weixlbaumer A, Petry S, Kelley AC, Weir JR, Ramakrishnan V. 2006. Structure of the 70S ribosome complexed with mRNA and tRNA. Science 313: 19351942.

Sizova DV, Kolupaeva VG, Pestova TV, Shatsky IN, Hellen CU. 1998. Specific interaction of eukaryotic translation initiation factor 3 with the $5^{\prime}$ nontranslated regions of hepatitis $C$ virus and classical swine fever virus RNAs. J Virol 72: 4775-4782.

Spahn CM, Kieft JS, Grassucci RA, Penczek PA, Zhou K, Doudna JA, Frank J. 2001. Hepatitis C virus IRES RNA-induced changes in the conformation of the 40s ribosomal subunit. Science 291: 19591962.

Stoneley M, Paulin FE, Le Quesne JP, Chappell SA, Willis AE. 1998. C-Myc 5' untranslated region contains an internal ribosome entry segment. Oncogene 16: 423-428.

Terenin IM, Dmitriev SE, Andreev DE, Shatsky IN. 2008. Eukaryotic translation initiation machinery can operate in a bacterial-like mode without eIF2. Nat Struct Mol Biol 15: 836-841.

Tsukiyama-Kohara K, Iizuka N, Kohara M, Nomoto A. 1992. Internal ribosome entry site within hepatitis C virus RNA. J Virol 66: 14761483.

Wang C, Sarnow P, Siddiqui A. 1993. Translation of human hepatitis $\mathrm{C}$ virus RNA in cultured cells is mediated by an internal ribosomebinding mechanism. J Virol 67: 3338-3344.

Wang C, Le SY, Ali N, Siddiqui A. 1995. An RNA pseudoknot is an essential structural element of the internal ribosome entry site located within the hepatitis $\mathrm{C}$ virus $5^{\prime}$ noncoding region. RNA 1: 526-537.

Wilson JE, Pestova TV, Hellen CU, Sarnow P. 2000. Initiation of protein synthesis from the A site of the ribosome. Cell 102: 511520.

Yusupova GZ, Yusupov MM, Cate JH, Noller HF. 2001. The path of messenger RNA through the ribosome. Cell 106: 233-241. 

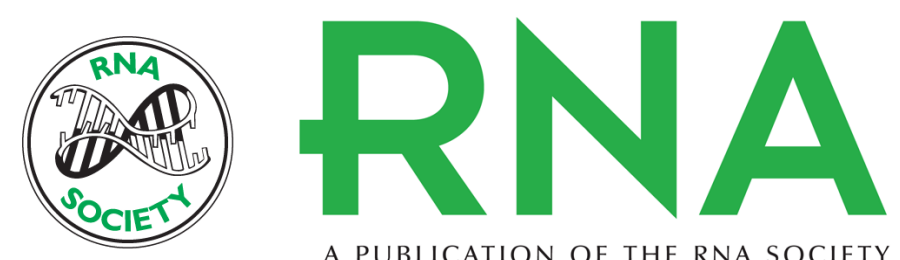

A PUBLICATION OF THE RNA SOCIETY

\title{
HCV IRES domain Ilb affects the configuration of coding RNA in the 40 subunit's decoding groove
}

\author{
Megan E. Filbin and Jeffrey S. Kieft
}

RNA 2011 17: 1258-1273 originally published online May 23, 2011

Access the most recent version at doi:10.1261/rna.2594011

$\begin{array}{ll}\text { References } & \begin{array}{l}\text { This article cites } 63 \text { articles, } 28 \text { of which can be accessed free at: } \\ \text { http://rnajournal.cshlp.org/content/17/7/1258.full.html\#ref-list-1 }\end{array}\end{array}$

License

Email Alerting Receive free email alerts when new articles cite this article - sign up in the box at the Service top right corner of the article or click here. 